\title{
A constitucionalização da política: entre o inevitável e o excessivo
}

\author{
Eduardo Mendonça ${ }^{1}$
}

\begin{abstract}
RESUMO:
O trabalho aprecia o fenômeno da judicialização da política que implica na interferência do Poder Judiciário na definição de políticas públicas e no desenho institucional brasileiro. É destacado o papel da Constituição como norma maior balizadora não só do julgador, mas também do agente político. Ademais, aponta-se as vantagens da Jurisdição Constitucional, sobretudo para a afirmação das minorias, dentro do ativismo judicial.
\end{abstract}

Palavras-chave: Ativismo Judicial, Políticas Públicas, Instituição, Poder Judiciário, democracia, minorias.

\begin{abstract}
:
The study assesses the phenomenon of legalization of politics that involves the interference of the judiciary in defining public policies and institutional design in Brazil. It highlights the role of the Constitution as a higher standard majorettes not only to the judge, but also to the political agent. Moreover, it points to the advantages of the Constitutional Jurisdiction, especially for the empowerment of minorities within the judicial activism.
\end{abstract}

Keywords: Judicial Activism, Public Policy, Institution, judiciary, democracy, minorities.

\section{Introdução}

Nos últimos anos, tornaram-se comuns as referências à judicialização da política ou mesmo à politização da justiça no Brasil, indicando a crescente interferência do Poder Judiciário, especialmente do Supremo Tribunal Federal, na definição das políticas públicas e do próprio desenho institucional brasileiro ${ }^{2}$. Essa proeminência judicial é potencializada pela valorização dos princípios jurídicos e pelo desenvolvimento de uma dogmática nãoformalista, que acaba alargando a dimensão criativa inerente à interpretação jurídica e abrindo espaço para um contato mais estreito entre direito e moral também no momento da aplicação jurídica $^{3}$. Tais elementos - que, a rigor, gravitam em torno da ascensão judicial - constituem o

\footnotetext{
1 Mestre e doutorando em Direito Público na UERJ. Professor da Pós-graduação lato sensu da UERJ (CEPED).

2 Giselle Cittadino, "Judicialização da política, constitucionalismo democrático separação de Poderes". In: Luiz Werneck Vianna (Org.). A Democracia e os três Poderes no Brasil, 2002; Luis Roberto Barroso. Judicialização, ativismo judicial e legitimidade democrática, Revista de Direito do Estado no 13, 2009, pp. 7191; e Oscar Vilhena Vieira, Supremocracia. In: Daniel Sarmento (coord.), Filosofia e teoria constitucional contemporânea, 2009, pp. 483-502.

3 Vale o registro, porém, de que a relação entre direito e moral pode ser mediada por diferentes perspectivas filosóficas. Desde o positivismo inclusivo - que admite uma relação contingente, decorrente da positivação de princípios que se abram para avaliações morais - até as teorias não-positivistas, que defendem a existência de uma conexão necessária entre os dois elementos. Nessa última linha, a qual se adere, defendendo que a moral penetra o direito a partir de uma natural pretensão de correção da ordem jurídica, entendida como repúdio à injustiça deliberada ou consciente, v. Robert Alexy, La institucionalización de la justicia, 2005, p. 32.
} 
cerne do chamado neoconstitucionalismo, termo particular que designa uma realidade bastante abrangente ${ }^{4}$.

Diante desse quadro, a doutrina oscila entre a defesa apaixonada e a crítica ferrenha, especialmente sob o argumento de que a judicialização esvaziaria os espaços de deliberação majoritária e enfraqueceria o ideal de autogoverno democrático. O risco é real e será objeto de consideração. No entanto, o objetivo do presente estudo é investigar essa nova realidade sob uma perspectiva que se pretende um pouco diversa, questionando se não teria havido uma alteração profunda na estrutura estatal e na própria ideia de autogoverno. Em outras palavras, a hipótese a ser testada apresenta o neoconstitucionalismo como uma realidade histórica, certamente influenciada e influenciável pela teoria jurídica, mas não propriamente uma criação sua.

Com efeito, longe de constituir uma peculiaridade nacional ou limitada, o fenômeno tem sido observado em países que apresentam as mais diversas tradições jurídicas e arranjos sociais, do Brasil à Nova Zelândia ${ }^{5}$. Essa unidade na diversidade parece apontar para a emergência de um novo modelo de Estado $^{6}$, associado a sociedades cada vez mais complexas e à consolidação de premissas teóricas como o dogma democrático ${ }^{7}$ - em uma versão que não

4 Como relata Daniel Sarmento, o termo neoconstitucionalismo surgiu no debate espanhol e italiano, de onde foi importado para o Brasil, sobretudo após a difusão, no país, da coletânea editada por Miguel Carbonell, intitulada Neoconstitucionalismo(s), de 2003. No Brasil, para uma visão geral e crítica sobre o tema, v. Daniel Sarmento, "O neoconstitucionalismo no Brasil: riscos e possibilidades". In: Daniel Sarmento (coord.), Filosofia e teoria constitucional contemporânea, 2009, pp. 113-46; Luís Roberto Barroso, Neoconstitucionalismo e a constitucionalização do Direito ( $O$ triunfo tardio do direito constitucional no Brasil), Revista de Direito Administrativo $n^{\circ}$ 240, 2005; e Antonio Cavalcanti Maia, "Nos vinte anos da Carta Cidadã: do pós-positivismo ao neoconstitucionalismo". In: Daniel Sarmento, Cláudio Pereira de Souza Neto e Gustavo Binenbojm, Vinte anos da Constituição Federal de 1988, 2009.

5 Uma análise ousada das experiências de Canadá, Nova Zelândia, Israel e África do Sul encontra-se em Ran Hirschl, Towards juristocracy, 2007, estudo em que o autor levanta a tese de que a judicialização poderia ser favorecida pelas elites políticas e econômicas, enfraquecidas no sistema político. Não é necessário concordar com a avaliação para constatar a judicialização naqueles países. Para um diagnóstico claro de judicialização na Europa ocidental e na União Européia em geral, sob a influência da Corte Européia de Justiça, v. Alec Stone Sweet, Governing with judges - Constitutional politics in Europe, 2000.

6 Nessa linha, identificando o neoconstitucionalismo como uma nova forma de Estado de direito, decorrente de uma compreensão igualmente nova acerca do papel das Constituições e do arranjo entre os Poderes, v. Antonio Cavalcanti Maia, "Nos vinte anos da Carta cidadã: do pós-positivismo ao neoconstitucionalismo". In: In: Daniel Sarmento, Cláudio Souza Neto e Gustavo Binenbojm, Vinte anos da Constituição Federal de 1988 (coords.), 2009, pp. 148-50.

$7 \quad$ Ian Shapiro, Os fundamentos morais da política, 2006, p. 245: "O fato de que governos das mais diversas colorações ideológicas, em todos os cantos do mundo, tentem se cobrir com o manto da democracia é uma prova a mais - se preciso fosse - de que o compromisso com a democracia é um componente indispensável da legalidade política. Os aspirantes à liderança política podem ser progressistas ou conservadores, meritocratas ou igualitaristas, nacionalistas ou cosmopolitas, multicuturalistas ou defensores de uma única cultura. É muito mais difícil para eles opor-se abertamente à democracia - o que raramente acontece - do que adotar qualquer uma dessas posições. Podem acatar as deturpações ou desvios da democracia, ou afirmar que determinado sistema de representação democrática é injusto. Podem discutir a respeito do significado da democracia e das instituições que ela exige. Podem até defender a tese de que seu país 'ainda' não está preparado para a 
se reduz à regra majoritária - e o discurso ocidental dos direitos humanos. Não é crível que todos esses países tenham chegado a um denominador relativamente comum apenas por conta da leitura dos mesmos autores. Assim como as revoluções liberais não foram inventadas por Locke ou Rousseau. O Estado neoconstitucional - a despeito das variações que o rótulo comporta - é hoje uma realidade a ser estudada.

Sob esse ponto de vista, há muito espaço para a melhoria do desenho institucional e até para a proposição de modelos alternativos, inclusive com o objetivo de conter o decisionismo judicial e incrementar ou recuperar a capacidade de intervenção efetiva do legislador na orientação política. Apesar disso, é preciso ter o cuidado de não teorizar sobre nuvens, denunciando violações a um modelo de democracia e de separação dos Poderes que não mais existe e provavelmente não pode mais existir ${ }^{8}$. Em vez disso, pretende-se defender a ideia de que, no Estado neoconstitucional, a legitimação do poder pela representação eleitoral deve continuar a deter a primazia, mas passa a conviver e a exigir a complementação de novas formas de legitimação associadas ao paradigma da democracia deliberativa.

Nesse ambiente, parece possível observar o surgimento de um sistema institucional complexo, que se pretende democrático e atribui esse qualificativo às decisões por ele produzidas. Todas elas sujeitas a um dever de fundamentação e expostas à crítica pública e à possibilidade de revisão permanente. De forma específica:

(i) perde força a ideia - em si romantizada - de que o legislador seria capaz de exercer uma orientação completa e exauriente da vida política e social. Isso não pressupõe que se negue a primazia das suas intervenções, mas apenas que se reconheça a sua limitação empírica;

(ii) a política se vê a obrigada a traduzir suas pretensões em argumentos do catálogo mais ou menos definido de razões públicas. Pelo menos no que concerne às suas premissas básicas. Nesse sentido, ocorre uma certa constitucionalização da política ${ }^{9}$. Não apenas por conta das limitações que a Constituição impõe coativamente à deliberação majoritária, mas também

democracia - reconhecendo-lhe a legitimidade no mesmo momento em que se esquivam dela. No mundo contemporâneo, portanto, a aprovação à ideia de democracia é praticamente inegociável”.

8 Não é necessário ser um defensor do ativismo judicial para chegar a mesma conclusão. Embora não seja um entusiasta da jurisdição constitucional e critique severamente o que identifica como excessos retóricos do Tribunal Constitucional alemão, Habermas reconhece a impossibilidade de aferir a legitimidade das instituições contemporâneas pelos paradigmas jurídicos que se construíram no Estado social e, sobretudo, no Estado liberal, v. Jürgen Habermas, Faktizität und Geltung - Beiträge zur Diskurstheorie des Rechts und des demokratischen Rechtsstaats, 1998, pp. 306-7.

9 O termo política constitucional aparece de forma explícita, e.g., em Gustavo Zagrebelsky, El derecho dúctil, 2008, p. 17. Com ele o autor procura identificar o fato de que a convivência entre os muitos conteúdos constitucionais, potencialmente contraditórios, deve ser definida por um processo político permanente. A necessária coexistência desses conteúdos é que seria o núcleo rígido de uma Constituição pluralista. Em última instância, essa ideia básica será referendada no presente estudo, com a ressalva de que o referido processo político não se constitui apenas por mecanismos de decisão majoritária e deve levar a sério as exigências de fundamentação e igual respeito inerentes à democracia deliberativa. 
pela incorporação espontânea - e, sem dúvida, estratégica - do discurso da Constituição por parte do sistema político. Especialmente do discurso dos direitos fundamentais, que se torna constitutivo - e não mais limitativo - da democracia;

(iii) o Judiciário, por sua vez, se legitima como participante do processo deliberativo por manejar esse mesmo conjunto de argumentos. E se é verdade que o faz de forma mais limitada do que os agentes políticos, também é verdade que pode impor uma interpretação autoritativa sobre o conteúdo mínimo ou necessário das exigências constitucionais. De qualquer forma, deve estar aberto ao diálogo institucional, já que não é o rei absoluto do processo deliberativo ou dono da Constituição.

Por fim, cabe uma advertência ainda a título de introdução, de forma a identificar a pré-compreensão subjacente ao estudo. O diagnóstico institucional aqui contido não tem a pretensão de ser neutro, mas igualmente não se assume como mera projeção de um desejo. Pelo menos não conscientemente, e certamente não em toda a sua extensão. Pessoalmente, vejo potencialidades no ativismo judicial, ao mesmo tempo em que não identifico, na história brasileira, momentos em que as Cortes tenham barrado, efetiva e sistematicamente, orientações políticas relevantes ${ }^{10}$. Apesar dessa apreciação otimista e pouco assustada da judicialização no Brasil, reconheço a necessidade urgente de um fortalecimento da deliberação parlamentar, bem como a importância de uma cultura política não-judicializada. E por isso mesmo o estudo dará destaque à necessidade de autocontenção, crítica pública e até de alguma contenção externa ao poder judicial.

\section{A gênese moderna do autogoverno e o advento do Estado legislativo de direito}

Como referido, os elementos característicos do neoconstitucionalismo convergem para uma participação ativa do Judiciário nas escolhas políticas, notadamente por meio da interpretação de enunciados normativos de textura aberta. Isso desperta questionamentos sobre um possível esvaziamento da democracia, que pressupõe o autogoverno dos indivíduos,

\footnotetext{
10 Para o bem ou para o mal, não tivemos ainda nossa Era Lochner ou nossa Corte Warren, sem prejuízo das muitas intervenções relevantes do STF ou mesmo do Judiciário como um todo em questões de grande significação. Talvez se possa até dizer que os tribunais estejam pavimentando o caminho para essa eventualidade. Se um governo do PSOL assumisse a Presidência da República nas próximas eleições, talvez ocorresse uma confrontação mais intensa. De qualquer forma, o que se vai defender é que o equilíbrio entre ativismo e autocontenção é dinâmico e tem de ser estudado em concreto. E, a partir dessa premissa, não me parece que o Judiciário brasileiro tenha barrado a adoção de orientações políticas abrangentes e dominantes ou compelido o sistema político a adotá-las.
} 
diretamente ou - o que é mais realista - por meio de representantes eleitos. Antes de apresentar os argumentos que permitem repensar a ideia de autogoverno, convém repassar brevemente os fundamentos básicos do conceito.

Sem prejuízo de sua gênese na antiguidade grega, a democracia se incorporou à tradição política a partir das revoluções liberais que marcam o advento do constitucionalismo. A superação do absolutismo se deu pela afirmação da igualdade formal de todos os membros do povo, que reclamam para si o direito de constituir uma determinada ordem política ${ }^{11}$. Tal afirmação se deu sob a inspiração de um jusnaturalismo de base racional, filho do iluminismo, cujas premissas centrais foram positivadas nas Constituições. Com exceção da experiência norte-americana - que, por circunstâncias particulares, logo evoluiria para o controle judicial de constitucionalidade - a responsabilidade de guardar tais premissas foi conferida ao Parlamento, idealizado como intérprete autorizado da razão ${ }^{12}$. Razão da burguesia vitoriosa, como bem se sabe, que deveria ser protegida das intromissões de um corpo de juízes ainda fortemente associado com a aristocracia decadente.

O constitucionalismo nasce, portanto, sob a forma de Estado legislativo de direito, embalado pela homogeneidade dos parlamentos e pela baixa complexidade e caráter seletivo da intervenção do Poder Público na vida econômica e social ${ }^{13}$. É nesse ambiente que o Poder Legislativo assume a responsabilidade precípua pela orientação da vida política. Embora as Constituições existissem com o propósito de limitar o poder, a sua interpretação e construção ficava a cargo das maiorias políticas. Sob o domínio da igualdade formal, a democracia praticamente se esgotava na regra majoritária, não se admitindo que as decisões parlamentares pudessem ser efetivamente limitadas por uma instância não eleita ${ }^{14}$.

$\mathrm{O}$ advento do Estado social - em resposta às tensões acumuladas pelas condições materiais degradantes - não alteraria substancialmente essa associação entre democracia e regra majoritária ${ }^{15}$. A legislação social, inicialmente introduzida na Alemanha de Bismarck e

11 Não por acaso, é esse o momento de formação da teoria do poder constituinte, cuja manifestação seminal se encontra no manifesto do abade Sieyès, na qual defendeu que o Terceiro Estado - a massa que não pertencia ao clero e à nobreza - representava a verdadeira nação francesa e, como tal, poderia dar a si um novo regime. Como se sabe, a obra era sugestivamente intitulada "O que é o terceiro Estado?", podendo ser encontrada em edição brasileira sob o título A constituinte burguesa.

12 Eduardo García de Enterría, La Constitución como pacto social y como norma, 2003, p. 13: "La Asamblea, como representante del pueblo, queda investida de todos los poderes de manera absoluta, todos los que al pueblo originario corresponden, que nada ni nadie podría condicionar".

${ }_{13}$ Luigi Ferrajoli, Pasado y futuro del Estado de derecho. In: Miguel Carbonell (org.), Neoconstitucionalismo(s), 2003, p. 18.

14 Daniel Sarmento, "O neoconstitucionalismo no Brasil: riscos e possibilidades". In: Daniel Sarmento (coord.), Filosofia e teoria constitucional contemporânea, 2009, p. 116.

15 Sobre o referido percurso histórico, v. Paulo Bonavides, Do Estado Liberal ao Estado Social, 1996; e Dieter Grimm, Recht und Staat der bürgerlichen Gesellschaft, 1987, pp. 138-161. 
depois transposta para o plano constitucional, também é produto das maiorias políticas, estimuladas pela necessidade de manter sob controle os movimentos sociais e ideais igualitários que haviam se formado no século XIX. E até pela penetração dessas ideias nos parlamentos, especialmente por conta da ampliação do sufrágio.

No que concerne ao papel do Judiciário, é certo que a visão teórica que procurava negar à sua atividade qualquer conteúdo decisório foi substituída por elaborações mais sofisticadas e realistas. Não tanto por força das discussões que permearam o surgimento do Estado social, mas sim pelo natural desenvolvimento teórico e pela diminuição da associação entre os juízes e a antiga ordem. O próprio positivismo normativista de Kelsen - de matriz claramente liberal - reconhecia a dimensão criativa inerente à jurisdição. Ainda assim, defendia uma visão minimalista de Constituição, justamente para evitar a transferência de poder das maiorias para os tribunais ${ }^{16}$. Em essência, portanto, é possível dizer que a posição institucional do Judiciário não sofre alterações substanciais.

Do ponto de vista da organização e do equilíbrio entre os Poderes, a grande novidade do Estado social é, sem dúvida, o começo de um declínio na capacidade do legislador de exercer a orientação política, pela perda de homogeneidade dos parlamentos e, sobretudo, pela ascensão da Administração, agigantada pelo controle material e pelo domínio sobre a informação relacionada às muitas novas tarefas assumidas pelo Poder Público ${ }^{17}$. Além disso, nas potências centrais, o período de constitucionalização do Estado social coincide em grande parte com a aguda crise econômica de 1929 e com as duas guerras mundiais, acontecimentos que naturalmente favoreceram a concentração de poder no Executivo.

Sem prejuízo desse enfraquecimento de fato, é possível dizer que a predominância do Poder Legislativo nas decisões políticas nunca deixou de ser um discurso forte. Nem se defende que isso deva mudar radicalmente, uma vez que o fundamento dessa visão é a ideia de que os parlamentos (ainda) são a instância mais representativa da sociedade como um todo. Mais até do que um Poder Executivo cujo chefe seja eleito de forma direta, uma vez que este representa um projeto majoritário de poder, sem representação formal das minorias. Nesse

16 Hans Kelsen, Jurisdição constitucional, 2003, pp. 169-70: "É claro que a Constituição não entendeu, empregando uma palavra tão imprecisa e equívoca quanto a de justiça, ou qualquer outra semelhante, fazer que a sorte de qualquer lei votada pelo Parlamento dependesse da boa vontade de um colégio composto de uma maneira mais ou menos arbitrária do ponto de vista político, como o tribunal constitucional. Para evitar tal deslocamento de poder - que ela com certeza não deseja e que é totalmente contra-indicado do ponto de vista político - do Parlamento para uma instância a ele estranha, e que pode se tornar representante de forças políticas diferentes das que se exprimem no Parlamento, a Constituição deve, sobretudo de criar um tribunal constitucional, abster-se desse gênero de fraseologia, e se quiser estabelecer princípios relativos ao conteúdo das leis, formulá-los da forma mais precisa possível”.

17 Para uma análise da mudança por que passou a reserva de lei e a pretensão orientadora do legislador, na linha dos argumentos expostos no texto, v. Dieter Grimm, Die Zukunf der Verfassung, 1991, pp. 166-175. 
sentido, a arena política, especialmente o parlamento, apresenta-se como fórum natural do autogoverno, espaço em que a autonomia moral dos indivíduos se manifesta em sua dimensão pública. Na quadra atual, sequer se cogita de uma democracia sem tal componente. Nada obstante, a percepção contemporânea de democracia tampouco se esgota nisso.

\section{O Estado constitucional de direito e o surgimento de uma forma substancial de autogoverno}

Como se procurou demonstrar, a concepção de democracia desenvolvida a partir das revoluções liberais baseava-se essencialmente na tomada de decisões por parte das maiorias parlamentares. Sem prejuízo do reconhecimento explícito de um catálogo de direitos fundamentais, basicamente relacionados à proteção da autonomia privada dos indivíduos, não se aplicava a sério a ideia de que tais direitos pudessem constranger a deliberação majoritária. Sobretudo não pela forma de uma jurisdição constitucional efetiva. No domínio da autonomia pública, a igualdade formal ainda era a preocupação essencial.

E a verdade é que é nesse domínio que se atribui conteúdo aos direitos. Um catálogo de direitos fundamentais - como a Declaração de Direitos do Homem e do Cidadão, de 1789 - ficava incompleto se os cidadãos podiam decidir, sem restrições, sobre a conformação última dos direitos dos homens. E a discussão relevante certamente era de conformação, já que ideias-força como a igualdade não estavam mais em cheque - salvo em contextos extremos, como se veria no nazismo - mas sim a sua extensão plena a grupos como negros, mulheres ou estrangeiros. Ou ainda a eventual exigibilidade de medidas redistributivas. E nessas questões não havia nenhuma força contramajoritária que pudesse se opor verdadeiramente às decisões do sistema político. Em outras palavras, é inegável que o Estado social introduziu alguma dimensão substancial à democracia, mas não ainda sob a forma de limites e exigência impostos com eficácia à decisão das maiorias. A política concedeu. E o discurso oficial ainda era o de que a direção política era tarefa do Parlamento, palco da deliberação proporcional das forças sociais relevantes.

Como se vem destacando, o objetivo do presente estudo não é atacar a democracia representativa. Ao contrário, não se questiona a predominância de suas intervenções no desenho institucional. Ainda que tais intervenções venham a ser mais seletivas, abandonando a premissa - combalida e velada, mas ainda presente - de que as decisões políticas só seriam 
realmente legítimas quando provenientes dos agentes eleitos ou por eles referendadas. O que se sustenta no presente estudo é uma visão dinâmica da democracia, que hoje se realiza por um desenho institucional complexo. Esse arranjo conserva a preferência dos representantes eleitos, mas comporta também espaços de decisão política contramajoritária, os quais ainda podem ser democráticos, sob uma perspectiva deliberativa.

Seria formalismo afirmar que não ocorre decisão política quando o STF determina que a troca injustificada de partido acarreta perda do mandato parlamentar. E ainda diz o que deve ser entendido como troca injustificada, valorando a lógica da atuação partidária e separando o que é ideológico do que seria meramente oportunista. Essa não era uma consequiência explícita do texto constitucional, ainda que seja uma leitura possível. Houve, sem dúvida, uma decisão política. De uma política diferente, menos livre do que a política majoritária e que, para ser legítima, não pode ter a pretensão de veicular necessariamente a palavra final e acabada no diálogo entre os Poderes. Mas ainda assim política, manifestação da necessidade de organizar a convivência do desacordo sobre uma base mínima de acordo ${ }^{18}$.

Essa decisão do STF - que se considera legítima, pelas razões que serão desenvolvidas adiante - demonstra que a legitimação democrática das decisões políticas talvez não possa mais repousar, unicamente, na manifestação das maiorias. Por meio da interpretação do Direito, decisões são introduzidas no espaço público. Decisões que não eram necessárias, já que a ordem jurídica, em muitos casos, dá margem a variadas interpretações. Essa dimensão criativa - que fica em evidência nas mudanças de jurisprudência ${ }^{19}$ - está presente em praticamente todas as operações de aplicação do direito, em maior ou menor grau ${ }^{20}$. E se há escolha entre opções, é evidente que não se pode falar de um espaço apolítico ${ }^{21}$. Não há como

18 Dallari de Abreu Dallari, Teoria geral do Estado, 1998, p. 48: "Diz Heller que o político é influenciado e condicionado pela totalidade do ser humano e, por sua vez, influencia e condiciona essa totalidade, acrescentando que o objeto específico da política consiste sempre na organização de oposições de vontade, sobre a base de uma comunidade de vontade".

19 Sobre as mudanças de jurisprudência e sua aproximação material com a criação de direito novo por parte do sistema político, v. Luís Roberto Barroso, Mudança da jurisprudência do Supremo Tribunal Federal em matéria tributária. Segurança jurídica e modulação dos efeitos temporais das decisões judiciais, Revista de Direito do Estado no 2, 2006, pp. 269-273.

20 E isso, por dois fundamentos. Em primeiro lugar, a generalidade dos conceitos jurídicos apresenta alguma dose de indeterminação, em si mesmos ou quando aplicados a situações imprevistas. Nesse sentido, afirmando que, salvo por alguns poucos conceitos verdadeiramente objetivos, a noção de lei é necessariamente tipológica e não abstrato-conceitual, v. Arthur Kaufmann, "Problemgeschichte der Rechtsphilosophie". In: Arthur Kaufmann, Winfried Hassemer e Ulfried Neumann (orgs.). Einfhürung in die Rechtsphilosophie und Rechtstheorie der Gegenwart, 2004, p. 135. Em segundo lugar, verifica-se uma interferência subjetiva do intérprete na própria avaliação da realidade, na identificação dos elementos de fato que serão valorados juridicamente.

$21 \quad$ Dieter Grimm, Constituição e política, 2006, p. 15: “Contudo, a separação entre direito e política no nível da aplicação do direito não significa que o procedimento de aplicação judicial do direito seja internamente apolítico, ou seja, não deixe espaço para nenhum tipo de decisões constitutivas ou não possa desenvolver nenhum efeito político que ultrapasse o efeito político das normas gerais". 
negar que, materialmente, essa atividade se aproxima de uma política constrangida pelas balizas do direito ${ }^{22}$. E muitas vezes são os próprios agentes políticos e grupos de pressão que provocam e intervenção judicial, incorporando o sistema judicial à sua atuação em sentido amplo.

Nesse sentido, o direito se aproxima da política e até pode ser apropriado como ferramenta de luta política. Inclusive por parte de grupos sociais que dificilmente teriam acesso adequado ao sistema político, mas que podem inserir suas pretensões no debate público a partir da arena judicial ${ }^{23}$. Ao mesmo tempo, a arena propriamente política se vê obrigada a traduzir seu discurso na linguagem da Constituição, mesmo que seja em sua franja mínima. Nenhum político que tenha pretensões mais sérias pode mais defender a discriminação, mesmo que procure desqualificar determinadas pretensões de reconhecimento, retirando-as da esfera de aplicação da igualdade.

Identificam-se, portanto, dois movimentos de aproximação entre direito e política. $\mathrm{O}$ risco intuitivo é a confusão de métodos, que deve ser evitada pelo controle permanente na esfera público e até por meio de disposições que impeçam os tribunais de se guiar pela lógica da política partidária ou suprimir o pluralismo das forças majoritárias em favor de um projeto perfeccionista qualquer ${ }^{24}$. O ponto será retomado. O que se quer destacar, no presente tópico, é o surgimento de uma legitimação discursiva ou deliberativa, como contraponto e até complemento à legitimação majoritária. Esse é um parâmetro aplicável a todas as

22 Luis Roberto Barroso. Judicialização, ativismo judicial e legitimidade democrática, Revista de Direito do Estado no 13, 2009, p. 80: “A Constituição faz a interface entre o universo político e o jurídico, em um esforço para submeter o poder às categorias que mobilizam o Direito, como a justiça, a segurança e o bem-estar social. Sua interpretação, portanto, sempre terá uma dimensão política, ainda que balizada pelas possibilidades e limites oferecidos pelo ordenamento vigente". Na mesma linha, v. Dieter Grimm, Constituição e política, 2006, p. 16: "Destarte, o conteúdo político da aplicação do direito é inevitável e, na mesma medida, a própria Justiça se constitui em um poder político. Contudo, permanece uma diferença, pois a aplicação do direito toma decisões de antemão dentro de um âmbito normativamente restrito. Ademais, ela não persegue objetivos políticos próprios e oferece, por isso, uma garantia maior de imparcialidade. E, por fim, ela também não é dependente de escolhas sucessivas e, por isso, obrigada a considerações estranhas a norma".

23 Sobre o tema, v. Boaventura de Souza Santos, A gramática do tempo - para uma nova cultura política, v. 4, 2006, p. 369. O autor destaca que a relação do Poder Público com os segmentos sociais ativos, especialmente o chamado terceiro setor, pode ser marcada por alguma conflituosidade, inclusive para forçar a abertura de novos canais de participação em domínios em que a democracia representativa penetre com baixa intensidade. De forma semelhante, afirmando que o terceiro setor pode levar aos canais políticos demandas sociais oriundas de setores pouco representados, v. Daniel Sarmento, Direitos fundamentais e relações privadas, 2004 , p. 3.

24 Como será desenvolvido adiante, a partir da igualdade essencial dos participantes de uma comunidade política se constrói o conceito de autonomia moral, aplicável à esfera púbica e privada. Isso impede que os valores e as concepções majoritárias sejam impostos de forma indiscriminada, sobretudo quando o modo de ser, as opções existenciais e as preferência do indivíduo não produzam agressão à esfera jurídica protegida de terceiros. O tema envolve muitas complexidades adicionais e só se pretendia destacar a resistência que o princípio da igualdade e a própria democracia opõem aos excessos majoritários, não apenas na esfera pública, mas também no domínio das escolhas de foro íntimo. Sobre o tema, v. Carlos Santiago. Nino, Ética y derechos humanos, 1989, especialmente a p. 199 e ss. 
manifestações de poder estatal, mas um de seus subprodutos é a abertura de maiores oportunidades para a interferência da jurisdição constitucional nas decisões políticas ${ }^{25}$. Como referido inicialmente, a abordagem se pretende reconstrutiva, extraindo de um diagnóstico da realidade institucional fundamentos para a melhoria do sistema.

É possível identificar dois fatores essenciais para o surgimento de uma legitimação deliberativa. O primeiro - determinante para o argumento que se quer desenvolver - guarda relação com alterações profundas na filosofia política dominante, que expandiu a dimensão substantiva da democracia e revitalizou a razão prática no preenchimento do seu conteúdo. O segundo fator se baseia em uma mudança igualmente profunda na estrutura do Estado e do Direito, motivada pelo aumento da complexidade da sociedade e das intervenções que se espera do Poder Público. Nesse contexto, defender a primazia do legislador não se confunde com ignorar a existência necessária de outras instâncias decisórias, quer destinadas à concretização de orientações políticas gerais - como as agências reguladoras -, quer destinadas à concretização das normas jurídicas de textura aberta, papel tipicamente desempenhado pelo Poder Judiciário. Especialmente pelos tribunais superiores, encarregados da decisão final ou mesmo originária nas questões de maior significação política, inclusive por conta das regras de competência ${ }^{26}$.

25 Robert Alexy, Ponderação, jurisdição constitucional e representação popular. In: Cláudio Pereira de Souza Neto e Daniel Sarmento (orgs.), A Constitucionalização do Direito - Fundamentos teóricos e aplicações específicas, 2007, p. 302: "Um conceito adequado de democracia deve, entretanto, compreender não apenas decisão, mas também argumento. A inclusão da argumentação no conceito de democracia cria a democracia deliberativa. A democracia deliberativa é uma tentativa de institucionalizar o discurso enquanto um mecanismo possível de tomada de decisões políticas. Por essa razão, a conexão entre o povo e o parlamento não deve ser unicamente determinada por decisões expressas, eleições e votos, mas também por argumentos. Nesse sentido, a representação do povo pelo parlamento é, ao mesmo tempo, volitiva ou decisional e argumentativa ou discursiva". Vale o registro de que o autor aplica esse conceito de legitimação discursiva também ao Tribunal Constitucional, reforçando sua posição.

26 De certa forma, é nas instâncias superiores que se concentra a maior capacidade de interferência do Judiciário nas questões políticas, especialmente no STF. Até pelo fato de que as instâncias ordinárias de aplicação do direito se vêem obrigadas a fornecer um serviço público de massa, o que dificulta maior reflexão. A observação se encontra em Daniel Sarmento, "Interpretação constitucional, pré-compreensões e capacidades institucionais do intérprete". In: Daniel Sarmento, Cláudio Souza Neto e Gustavo Binenbojm, Vinte anos da Constituição Federal de 1988 (coords.), 2009. O autor inclusive destaca que a sobrecarga judicial e a heterogeneidade dos magistrados devem ser levadas em conta ao se formular teorias hermenêuticas, que não devem pressupor capacidades institucionais inteiramente descoladas da realidade empírica. Sem prejuízo de se concordar com a linha geral do raciocínio, vale observar que a teorização que conduz ao desenvolvimento de construções judiciais não precisa se desenvolver de forma atomizada, em cada caso e muito menos por cada juiz isoladamente. Ao contrário, muitas vezes é possível observar alguma dose de sinergia na atuação dos diferentes agentes que integram o sistema judicial, dando origem à consolidação incremental de determinado entendimento. Essas observações não mudam o fato de que juízes - bons ou medíocres - terão de avaliar realidades de fato que podem ser complexas e aplicar as teorias, o que pode ser desastroso. Apenas se quis fazer o registro de que a disseminação de construções jurídicas mais sofisticadas não pressupõe, necessariamente, que cada juiz seja um filósofo. Sobre a idéia de incrementalismo - como estratégia e até como circunstância inerente ao sistema judicial -, v. Malcolm Feeley e Edward Rubin, Judicial policy making and the modern State - How courts reformed America's prisons, 2000, p. 235. De forma específica, a obra descreve os substanciais avanços que o Judiciário dos Estados Unidos produziu no sistema prisional daquele país. A questão é descrita em riqueza de 
Após essas considerações gerais, passa-se à análise específica de cada um dos fatores referidos.

\section{a) Democracia substantiva e razão prática. A mútua implicação entre autonomia pública e autonomia privada, a ser equacionada no espaço público}

Antes de tudo, cabe um esclarecimento. $\mathrm{O}$ que se pretende demonstrar, inicialmente, não é a legitimidade da jurisdição constitucional. Muito menos apresentá-la como uma obviedade ou uma instituição necessária. Ao contrário, a jurisdição constitucional será apresentada como uma instituição dotada de uma legitimidade contingente, sem prejuízo de sua ampla difusão e da existência de muitos argumentos que podem justificar sua adoção. Por outro lado - e essa é a etapa inicial do raciocínio - se vai defender que, no estágio atual do Estado de direito, a existência de uma legitimação discursiva é necessária, e não contingente. Não para substituir a legitimação majoritária, mas sim como complemento e, em certos casos, contraponto. Feita a ressalva, volte-se ao ponto.

O marco histórico do neoconstitucionalismo é o fim da segunda guerra mundial ${ }^{27}$. É possível observar essa virada por diversos aspectos, inclusive aquele que destaca a decadência do positivismo formalista, cuja fragilidade foi exposta no Tribunal de Nuremberg. O enfoque aqui será outro, afirmando-se que, a partir dali, a própria ideia de autogoverno passou por uma alteração profunda. A democracia se substantivou de uma forma não antes vista, criando a percepção palpável de que as maiorias devem estar sujeitas a limites efetivos. Nesse sentido, a democracia continuou sendo o governo da maioria, mas com a ressalva de que certas condições democráticas são indispensáveis e podem ser impostas como condição de legitimidade.

Do ponto de vista puramente teórico, essa talvez não tenha sido uma virada copernicana. No fundo, a regra majoritária se assenta em uma premissa substantiva, que é a igualdade essencial dos participantes do processo decisório ${ }^{28}$. Entre um senhor e mil escravos, a regra majoritária não opera por necessidade lógica. É entre iguais que faz sentido impor a maioria de votos como critério para a tomada de decisões vinculantes para todos. É assim que

detalhes e analisada também por Marcos Maselli Gouvêa, O controle judicial das omissões administrativas, 2003

27 Luís Roberto Barroso, Curso de direito constitucional contemporâneo - Os conceitos fundamentais e a construção do novo modelo, 2009, pp. 245-7.

28 Ana Paula de Barcellos, A eficácia jurídica dos princípios constitucionais, 2002, p. 229 e Oscar Vilhena Vieira, Supremo Tribunal Federal-Jurisprudência política, 2002, p. 26 
autodeterminação se converte em autovinculação ${ }^{29}$. Em autogoverno, portanto. No entanto, até do ponto de vista lógico, tal conversão nunca pode dar origem a um procedimento que trate os indivíduos como meros objetos de decisão, e não como partícipes da comunidade política. Discriminar as minorias de hoje nega a premissa democrática e, em termos práticos, reduz sua chance de se tornarem maiorias no futuro, transformando-as em sujeitos de uma dominação permanente e não mais de um arranjo democrático. Além disso, a multiplicidade de valores e pontos de vista existentes na sociedade tende a não permitir uma clivagem perfeita entre maioria e minorias, sendo possível que diferentes temas produzam polarizações variadas.

Como se vê, a necessidade de que os processos decisórios não se transformem em instrumento para a dominação de nenhum grupo ou segmento social, por mais expressivo que seja, pode ser extraída diretamente dos fundamentos do princípio democrático ${ }^{30}$, sobretudo em um contexto marcado pelo fato do pluralismo ${ }^{31}$. No entanto, essa premissa básica tinha ficado obscurecida, ou, quando menos, não havia sido levada às suas últimas conseqüências. Essa é a marca distintiva da democracia substantiva do segundo pós-guerra: as condições mínimas da igualdade essencial de todos os homens - da sua dignidade humana - deveriam ficar protegidas de eventuais investidas majoritárias.

O retorno ao jusnaturalismo - ensaiado na Alemanha pós-nazista ${ }^{32}$ - foi provavelmente a manifestação mais explícita dessa ideia básica. Defender uma justiça suprapositiva era, de fato, uma reação perfeitamente compreensível em um ambiente confrontado com a crueldade em estado bruto produzida pela maioria, sob o amparo da ordem jurídica positiva. Mas não podia prosperar em um mundo desencantado, no qual a própria pretensão de impor uma verdade revelada seria tida como autoritária. Era necessário, portanto,

29 Thomas Fleiner-Gerster, Teoria geral do Estado, 2006, p. 434; e Hans Kelsen, Teoria geral do Direito e do Estado, 2005, p. 408-410.

$30 \quad$ Konrad, Hesse, Grundzüge des Verfassungsrechts der Bundesrepublik Deutschland, 1993, p. 57: "Como ordenação de um processo livre e aberto, não se trata apenas da justificação de uma dominação temporal e objetivamente limitada, legitimada pela maioria do povo, mas também de iniciativas e alternativas pluralistas. Ela [a ordenação democrática] permite a busca de objetivos políticos diferentes e também espaço para conflitos, e possibilita a sua conciliação; ela assegura, também sob este aspecto, chances iguais para a realização dos objetivos de cada um e abre a possibilidade de colaborar e influenciar também para os grupos que não pertencem à maioria investida na dominação" (Tradução livre).

$31 \quad$ John Rawls, Liberalismo político, 1996, p. 11.

Como registra Daniel Sarmento, o símbolo desse processo foi a famosa tese de Radbruch, de que normas terrivelmente injustas não poderiam ter validade jurídica. V. Daniel Sarmento, "O neoconstitucionalismo no Brasil: riscos e possibilidades". In: Daniel Sarmento (coord.), Filosofia e teoria constitucional contemporânea, 2009, pp. 128. Ainda sobre a tese de Radbruch, relatando que a experiência pessoal na Alemanha nazista fez o autor abandonar o pensamento positivista, entendendo que ele só seria aceitável em um período em que princípios básicos de moral já estivessem incorporados ao ordenamento positivo, v. Arthur Kaufmann, "Problemgeschichte der Rechtsphilosophie". In: Arthur Kaufmann, Winfried Hassemer e Ulfried Neumann (orgs.). Einführung in die Rechtsphilosophie und Rechtstheorie der Gegenwart, 2004, p. 228. 
justificar as condições democráticas - os limites que seriam impostos às maiorias - com base em um discurso que, em meio ao pluralismo de ideias, pudesse aspirar à aceitação geral. É nesse contexto que se verifica a reabilitação da razão prática pela filosofia política ${ }^{33}$, como forma de construir justificadamente os limites à deliberação majoritária, incorporados nas Constituições.

Ainda hoje, as teorias da justiça mais influentes se baseiam no pressuposto da razão prática. E nesses termos reconhecem, em alguma medida, a necessidade de uma legitimação discursiva das decisões políticas. Em outras palavras, reconhecem a cada indivíduo o direito fundamental de exigir argumentos, os quais não podem se assentar na negação de sua igual dignidade $^{34}$. Com a devida vênia, é possível dizer que esse ponto central une os dois troncos de pensamento mais influentes da teoria política contemporânea - liberalismo político e comunitarismo $^{35}$. Diga-se o mesmo do procedimentalismo e do substancialismo, que podem ser conceituados como teorias acerca do papel da Constituição na guarda da democracia. Demonstre-se o ponto ${ }^{36}$.

De forma muito simplificada, o liberalismo político se baseia na preferência do justo sobre o bem, e por isso defende que determinados direitos fundamentais devem ser tidos como logicamente anteriores à dinâmica política, ficando a salvo das maiorias ${ }^{37}$. O Estado deve permanecer neutro em relação às diferentes concepções razoáveis de vida boa, limitando-se a impor a pauta mínima de que se compõem a justiça política. A verdade, porém,

33 Como destaca o professor Ricardo Lobo Torres, essa mudança de paradigma - a chamada virada kantiana - teria como marco teórico fundamental a aparição de Uma teoria da justiça, publicada por John Rawls, em 1971. Sobre o tema, v. Ricardo Lobo Torres, Tratado de direito constitucional financeiro e tributário - Valores e princípios constitucionais tributários (v. II), 2005, p. 41.

$34 \quad$ Rainer Forst, Das Recht auf Rechtfertigung - Elemente einer konstruktivistischen Theorie der Gerechtigkeit, 2007, p. 255.

35 Para uma visão geral sobre liberalismo (igualitário) e comunitarismo, v. Rainer Forst, Das Recht auf Rechtfertigung - Elemente einer konstruktivistischen Theorie der Gerechtigkeit, 2007, pp. 224-248; e Will Kymlicka, Contemporary political philosophy - An introduction, 2002, pp. 53-101 e 208-83.

${ }_{36} \quad$ As considerações seguintes são inspiradas na obra de Rainer Forst, que descreve um modelo de democracia deliberativa baseado no direito à justificação, direito de cada membro de uma comunidade política a ser afetado somente por decisões baseadas em argumentos expostos no espaço público. O autor propõe essa concepção como forma de realizar o império dos argumentos (Herrschaft der Gründe), em oposição a um império dos princípios de justiça (identificado com o liberalismo de Rawls) ou a um império dos valores comunitários (que seria próprio das teorias de inspiração comunitarista). Com isso, entende que a democracia (deliberativa) é a única materialização institucional adequada - embora imperfeita - do direito fundamental à justificação e ao respeito recíproco titularizado por indivíduos autônomos que estejam ligados por um contexto político. V. Rainer Forst, Das Recht auf Rechtfertigung - Elemente einer konstruktivistischen Theorie der Gerechtigkeit, 2007, pp. 248-269. Vale o registro, porém, de que o autor apresenta sua teoria como alternativa ao liberalismo político e ao comunitarismo, ao passo que a ênfase do presente estudo será colocada em um ponto que parece aproximar ambas as correntes, que se assentam no reconhecimento de uma legitimação discursiva, ainda que tácita.

37 Ronald Dworkin, A matter of principle, 1985, pp. 191-2. Para um explicação do próprio Rawls acerca da origem kantiana da prioridade do justo sobre o bem, v. John Rawls, Lectures on the history of moral philosophy, 2003, p. 230 e ss. 
é que os princípios da justiça política não estão gravados em pedra, tendo de ser construídos racionalmente. $\mathrm{E}$, portanto, aceitos em uma comunidade argumentativa.

Na prática, não escapam a essa necessidade nem mesmo os autores que defendem um construtivismo ético aparentemente monológico. Afinal, nenhuma teoria da justiça se tornou influente porque seu autor teria acesso a algum botão vermelho ligado a armas nucleares, mas sim porque muitos indivíduos - mesmo que argumentando monologicamente - testaram suas premissas e validaram suas conclusões. No fundo, portanto, é no espaço público presente que aqueles limites são definidos, ainda que se possa invocar, como ferramenta de argumentação, a ideia de um momento pré-social. O propósito dessas considerações, evidentemente, não é desconstruir nenhuma versão particular e muito menos as bases do liberalismo político, que chama a atenção para a importância do esforço de definir direitos que sejam logicamente prévios à deliberação ordinária. Apenas se quer demonstrar que essa construção mental ganha conteúdo concreto em um processo que é, inevitavelmente, deliberativo. Eis aqui, portanto, a legitimidade discursiva da qual se falou.

O comunitarismo em sua melhor luz - como crítica comunitária ao liberalismo - não foge desse padrão. Ao contrário, o que ele faz é denunciar a fragilidade da ideia de um ser humano desenraizado e da pretensão de um Estado neutro em relação às diferentes concepções de bem $^{38}$. Para usar um exemplo expressivo, veja-se que um Estado inteiramente neutro teria pela frente uma dificuldade teórica ao proteger uma manifestação religiosa com mais intensidade do que a filiação a uma associação de bairro ou mesmo a um clube de futebol. Véus muçulmanos nas escolas ou crucifixos nas salas de audiência não deveriam aspirar à maior proteção do que um suposto direito do aluno e do juiz de comparecer a aula e presidir audiência envergando a camisa do Flamengo ${ }^{39}$. O valor diferenciado da liberdade de manifestar religião é construído socialmente. Nesse sentido, a importância que o comunitarismo confere aos valores sociais dominantes não é destituída de sentido, embora possa ser deturpada para justificar o perfeccionismo moral. Para evitar essa disfunção, é

38 Michael Walzer, Politics and passion - Towards a more egalitarian liberalism, 2006, p. 160. Nesse sentido, o que se coloca em disputa não é exatamente a existência de direitos, tampouco a possibilidade de que eles sejam exercidos em desacordo com valores ou preferências dominantes. O que se questiona é a possibilidade de que os direitos sejam definidos sem referência a alguma concepção anterior de moralidade social, como se a avaliação do justo fosse ontologicamente diversa da avaliação do bem. Nas palavras de Michael Sandel, Liberalism and the limits of justice, 2006, p. 186: "The term 'communitarism' is misleading, however, insofar as it implies that rights should rest on the values or preferences that prevail in any given community at any given time. Few if any of those who have challenged the priority of the right are communitarians in this sense. The question is not whether rights should be respected but whether rights can be identified and justified in a way that does not presuppose any particular conception of the good".

39 O exemplo é inspirado em Michael Sandel, Liberalism and the limits of justice, 2006, prefácio à segunda edição, p. xiii, onde o autor pergunta qual fundamento autorizaria a dispensa do trabalho concedida a judeus no Sabbath, mas não a dispensa de qualquer pessoa para assistir a um jogo de futebol (americano). 
necessário concluir que os valores sociais devem ser justificados por meio de argumentos que não desqualifiquem o interlocutor como igual participante da comunidade decisória.

Para chegar ao fundo do raciocínio, a pergunta que se impõe é: quais argumentos não desqualificam o interlocutor e podem justificar que lhe seja imposta uma decisão? E a verdade é que essa resposta também não está gravada em pedra, tendo de ser construída argumentativamente. Como visto, o mesmo pôde ser dito dos princípios da justiça de Rawls. E o mesmo raciocínio valeria para a discussão entre procedimentalismo e substancialismo: é no espaço público que serão definidas as condições procedimentais do discurso legítimo ou as decisões substanciais protegidas das maiorias.

Era essa mesmo, lembre-se, a tese que se queria defender: a visão contemporânea de democracia substantiva exige que as decisões estejam respaldadas por uma legitimação discursiva. É por meio dela que se confere conteúdo à máxima de que as maiorias não podem tudo. Isso pode parecer uma contradição ou uma inutilidade, como se estivesse sendo afirmado que as maiorias não podem fazer o que as próprias maiorias dizem não poder. Mas talvez não seja exatamente assim.

Apenas em parte - uma parte que se pretende inevitável - essa crítica é procedente. Em última instância, são as maiorias mesmo que decidem os seus limites, inclusive pela distinção (permanente) entre o que é constituinte e o que é constituído ${ }^{40}$. Nenhuma Constituição é imutável e nenhum Judiciário resistiria indefinidamente caso houvesse uma percepção generalizada de que se tornou anacrônico. O próprio poder constituinte originário marca uma (re)fundação do Estado apenas sob a perspectiva da teoria jurídica. Do ponto de vista político, é óbvio que se pode abrir o campo de visão e observar um processo político contínuo, incluindo os pontos em que se verificou uma modificação explícita de suas bases. Esse é o lado pessimista da constatação de que é no espaço público que se constroem todos os limites democráticos, até aqueles que tenham a pretensão de verdade atemporal.

O lado bom é que o espaço público não precisa ser entendido como um nome pomposo para a deliberação majoritária como rolo compressor. Em vez disso, a expressão designa um sistema complexo de instâncias deliberativas e fóruns decisórios que devem estar submetidos permanentemente à influência e à crítica. Nesse ambiente, qualquer resposta deve

40 Rainer Forst, Das Recht auf Rechtfertigung - Elemente einer konstruktivistischen Theorie der Gerechtigkeit, 2007, p. 249: “Ao contrário de uma forma muito forte de autotranscendência (como em Nagel) basta que pessoas racionais diferenciem dois contextos de justificação: o contexto ético, no qual se encontram as respostas a perguntas sobre conceitos de vida boa, que não precisam necessariamente ser capazes de consenso geral; e o contexto da validade de normas gerais, que devem se apoiar em argumentos a serem justificados em bases de reciprocidade e generalidade. Esses contextos não devem ser compreendidos como domínios valorativos separados a priori; em vez disso, são definidos discursivamente" (Tradução livre). No mesmo sentido, v. Jürgen Habermas, Entre naturalismo e religião. Estudos filosóficos, 2007, p. 322. 
ser vista como essencialmente provisória, a despeito da convicção compartilhada sobre determinados valores básicos, como a igualdade ou a liberdade. Até as decisões finais - por necessidade de superação dos impasses - devem ser tomadas como provisoriamente finais ${ }^{41}$. O Supremo Tribunal Federal pode mudar de ideia, uma lei ou ato do Executivo podem estabelecer diálogo com a decisão da Corte, uma emenda à Constituição pode ser aprovada, a própria Constituição pode ser substituída.

É lógico que esses eventos estão sujeitos a diferentes níveis de dificuldade, mas esse é justamente o ponto. Cada sociedade pode definir os elementos constitutivos do seu projeto político básico, entrincheirando-os de forma mais intensa. Basta olhar para a história para ver que essa divisória não é atemporal. Em muitos momentos, sequer foi reconhecida. E nada sugere que tenhamos chegado a um ponto definitivo. Aliás, daqui a 100 anos é bem possível que os valores dominantes classifiquem práticas atualmente aceitas - como extravagâncias gastronômicas em churrascarias-rodízio - como manifestações primitivas ou mesmo cruéis, seja pela difusão de uma cultura de respeito a direitos animais, seja por uma percepção crítica acerca da convivência entre tanta fartura e a miséria extrema vivenciada por mais da metade dos habitantes do globo.

Em suma, os limites às maiorias não descem do céu em meio a trovões. Em vez disso, são decididos por arranjos institucionais concretos e são sempre passíveis de revisão. O que se quis demonstrar é o fato de que a democracia atual, que emergiu do segundo pós-guerra, leva a sério a necessidade de impedir que a deliberação majoritária acabe por negar a premissa da igual dignidade dos participantes. Em termos de filosofia política, cuida-se da interdependência entre a autonomia privada e a autonomia pública - ambas dimensões da autonomia moral - ou ainda entre soberania popular e direitos fundamentais ${ }^{42}$. $\mathrm{O}$ raciocínio pode ser assim decomposto:

i) ao ser humano igualmente digno não se pode impor uma ordem política e jurídica sem a sua participação, o que seria uma forma de dominação. Aqui está a autonomia pública;

ii) de qualquer forma, o resultado da deliberação, a cada momento, não pode lhe negar a condição de sujeito igualmente digno, inclusive porque isso o impediria de permanecer engajado no processo de auto-governo. O reconhecimento da autonomia privada é, portanto, pressuposto da autonomia pública.

${ }_{41} \quad$ Nesse sentido, entendendo que a prática política - republicana - gera e revê continuamente suas próprias premissas jurídicas e de que disso decorre a atualidade da ideia de autogoverno v. Frank Michelman, Law's republic, 97 Yale Law Journal, 1493, July 1988.

42 Sobre a co-dependência entre direitos fundamentais e soberania popular sob o paradigma da democracia deliberativa, v. Cláudio Pereira de Souza Neto, Teoria constitucional e democracia deliberativa, 2006, pp. 128-135; e Marcelo Cattoni, Direito, política e filosofia, 2007, pp. 18-19. 
Toda essa operação mental, porém, se realiza no mundo concreto, em meio às profundas discordâncias nele verificadas. A forma de equacioná-las é essencialmente por meio da deliberação livre de constrangimentos, que complementa, portanto, a escolha majoritária. A decisão pela maioria continua tendo um valor intrínseco, mas não se esgota em si mesma. Os perdedores de cada processo decisório não se convertem em dominados, ostentando o direito fundamental a receber argumentos que não os desqualifiquem. Essa é a premissa básica que permite identificar a emergência de uma legitimação discursiva. E a partir disso, cada sociedade pode construir suas instituições sob os mais variados arranjos, inclusive por meio da previsão de instâncias que operam única ou essencialmente sob essa forma de legitimação. É o caso da jurisdição constitucional, que será analisada adiante.

Antes disso, é hora de abordar, ainda que de forma mais abreviada, o segundo dos fatores inicialmente descritos para identificar o surgimento de uma legitimação discursiva.

\section{b) A crise estrutural do Estado legislador}

O segundo elemento a ser apresentado não ostenta a mesma pretensão de dignidade filosófica do primeiro, mas talvez seja mais palpável. A rigor, o que se vai empreender é a tentativa de demonstrar que a legitimidade discursiva já está entre nós, e que dificilmente será suprimida sem alguma revolução radical na estrutura do Estado e da própria sociedade civil.

É fato que a sociedade e os campos de atuação estatal tornaram-se muito mais complexos, reduzindo a capacidade do legislador de exercer a direção política do Poder Público e dos poderes privados, cuja influência aumentou consideravelmente ${ }^{43}$. Como referido acima, um marco essencial dessa mudança foi o advento do Estado social, mas não se pode dizer que o panorama tenha se alterado substancialmente no Estado pós-social ou regulador. O Poder Legislativo, por sua vez, tornou-se muito mais heterogêneo, o que dificulta ainda mais qualquer ação coordenada. O resultado desse conjunto de fatores é a chamada crise dos Parlamentos ${ }^{44}$, que leva à perda de representatividade de suas decisões e ao deslocamento de poder normativo para outras instâncias, que também buscam se legitimar ${ }^{45}$.

43 Daniel Sarmento, Direitos fundamentais e relações privadas, 2004, 304. Especificamente sobre a necessidade de democratização dos espaços privados como requisito para a autonomia moral, v. p. 353 e ss.

44 Sobre o tema, enfatizando um ou outro dos aspectos referidos acima, v. Clèmerson Merlin Clève, Atividade legislativa do Poder Executivo, 2000, p. 45. e ss; e Manoel Gonçalves Ferreira Filho, Processo legislativo, 2007, p. 12 e ss. Para uma análise especialmente densa, abarcando todos os fatores referidos, v. Luis Prieto Sanchís, Ley, princípios, Derecho, 1998, p. 5 e ss.

$45 \quad$ Como se sabe, a própria legalidade passa por uma releitura e se converte em juridicidade, seja para admitir a aplicação direta da Constituição, seja para admitir amplas delegações legislativas, com parâmetros muitas vezes fluidos. Sobre os novos contornos do princípio da legalidade, v. Patrícia Baptista, Transformações 
A manifestação mais intuitiva desse fenômeno são as agências reguladoras. É óbvio que a razão prática não foi redescoberta para legitimar as decisões dessas autarquias especiais ou de quaisquer outras instâncias administrativas que, a despeito de pretensamente técnicas, acabam desenvolvendo pautas políticas gerais definidas no sistema propriamente político. Ainda assim, o conceito de legitimação por argumentos colocados no espaço público aproveita também a essas entidades, que têm sido consideradas legítimas e que dificilmente sumirão do mapa sem deixar algum sucessor mais ou menos similar. Ao mesmo tempo, a insuficiência do legislador nos (muitos) domínios regulados demonstra a necessidade de processos decisórios - ainda que complementares - legitimados pela capacidade institucional de manejar argumentos que se reputam valiosos.

A mesma linha argumentativa se aplica, com maior intensidade, ao Poder Judiciário, cuja função típica é a de garantir a aplicação regular da ordem jurídica, concretizando a garantia do Estado de Direito. No entanto, uma vez que essa mesma ordem jurídica apresenta uma textura crescentemente aberta, torna-se impossível deixar de reconhecer que o ato de aplicação envolve uma dimensão criativa e acaba interferindo no processo de conformação das políticas públicas.

Essa não é, a rigor, uma falha do sistema judicial, tampouco uma forma de usurpação da competência das instâncias políticas. Em essência, trata-se de uma circunstância inerente à interpretação de qualquer sistema de proposições lingüísticas, sobretudo quando seja permeado por valores. Adicionalmente, as próprias instâncias políticas contribuem para esse quadro, especialmente o legislador, que tem se valido cada vez mais de normas de textura aberta, por motivos diversos. Com efeito, ainda que alguma dose de indeterminação seja decorrente da própria linguagem ${ }^{\mathbf{4 6}}$, é notório que, muitas vezes, a adoção de níveis mais elevados de abertura semântica constitui uma opção do Poder Legislativo.

Nesse ambiente, a positivação de cláusulas abertas e conceitos parcialmente indeterminados pode decorrer da dificuldade de disciplinar em abstrato uma infinidade de situações imagináveis ou mesmo de uma opção política do Poder Legislativo, motivada, idealmente, pela convicção de que o administrador público ou o juiz terão melhores condições de avaliar as circunstâncias concretas e responder de forma adequada. Ou seja, a maleabilidade das normas jurídicas é manejada pelo próprio legislador, seja para viabilizar

do direito administrativo, 2003, p. 108; Alexandre Santos de Aragão, Direito dos serviços públicos, 2007, p. 324 e ss; e Gustavo Binenbojm, Uma teoria do direito administrativo - Direitos fundamentais, democracia e constitucionalização, 2006, p. 150 e ss.

46 Nesse sentido, com base no estudo de autores ligados à filosofia da linguagem, v. Noel Struchiner, Direito e linguagem, 2002, p. 15. 
consensos, seja para abarcar realidades complexas e cambiantes. Ou mesmo por incapacidade de estabelecer decisões específicas com a complexidade e no ritmo que seriam exigidos pela realidade moderna.

Interessantes estudos se propõem a discutir se essa transferência de poder deve ser vista como escolha política deliberada ou abdicação desesperada ${ }^{47}$, movida pela incapacidade legislativa de atender à demanda social por regulação jurídica. É provável que a resposta não seja única para todos os domínios e que, em boa parte deles, a verdade se encontre em algum ponto a meio caminho. Não é o caso de aprofundar a discussão. Basta constatar que, nesse contexto, invocar a relativa indefinição dos enunciados normativos para contestar a legitimidade da jurisdição constitucional não seria uma estratégia totalmente leal. É claro que essa argumentação não justifica, por si só, o ativismo como postura deliberadamente proativa, mas serve para demonstrar que a interferência do Judiciário na conformação política é até natural, sem prejuízo das gradações que ela pode assumir em cada experiência constitucional e momento histórico.

Nada do que se disse acima tem por objetivo impedir que o sistema político especialmente o legislador - produza decisões tão completas e específicas quanto seja capaz. Não se negou a preferência da legitimação majoritária, atendidas as exigências da legitimação discursiva $^{48}$. No entanto, defender o papel institucional do Poder Legislativo, e até conceber meios de dinamizar sua intervenção, não pressupõe que sejam desqualificadas outras sedes decisórias, e.g., pintando a jurisdição constitucional como um remédio amargo que até pode corrigir a democracia em nome do Estado de Direito, mas que estaria fora dela.

Tampouco se justifica que as críticas a essas instituições contramajoritárias se beneficiem de uma certa falácia do legislador Hércules, idealizando retoricamente as suas capacidades institucionais. Ou ainda desconsiderando a possível captura do processo legislativo por interesses privados organizados ou mesmo a simples inexistência de coincidência automática e necessária entre uma suposta vontade dos representantes e a

$47 \quad$ V. Roderick D. Kiewiet e Mathew Mccubbins, The logic of delegation, 1991; John D. Huber e Charles R. Shipan, Deliberate discretion - The institutional foundations of bureaucratic autonomy, 2002 e David Epstein e Sharyn O'Halloran, Delegating powers - A transaction cost politics approach to policy making under separate Powers, 1999.

$48 \quad$ A preferência da lei não é contestada nem mesmo pelos autores que entendem possível a chamada deslegalização, uma vez que não pretendem retiram do Poder Legislativo a possibilidade de tomar decisões específicas e mesmo de retomar o controle sobre matérias delegadas ou mesmo deslegalizadas. A título de exemplo, v. Alexandre Santos de Aragão, Agências reguladoras e a evolução do direito administrativo econômico, 2006, pp. 422-423. 
vontade dos representados ${ }^{49}$. A deliberação parlamentar tem valor intrínseco ainda quando seja impopular ${ }^{50}$. Não é preciso situá-la atrás do espelho.

Veja-se que tais advertências não decorrem da especial crise de representatividade do Congresso Nacional brasileiro. Ainda que o seu estado de crise permanente possa exigir soluções institucionais específicas - e, sem dúvida, dificulte uma reação institucional a eventual ativismo -, os argumentos aqui desenvolvidos não se prendem a essa conjuntura. Mundialmente, o Poder Legislativo tem enfrentado a diminuição da sua capacidade de direção política da sociedade complexa, e isso tem resultado em alguma partilha da sua competência normativa com outras instâncias. Não é preciso desejar essa realidade para reconhecer que qualquer teoria deve levá-la em consideração.

\section{Democracia deliberativa e Política constitucional, sem (muitas) idealizações}

\section{a) legitimação discursiva e política constitucional}

Nos tópicos precedentes se procurou assentar a tese de que a concepção contemporânea de democracia substantiva envolve necessariamente uma dimensão deliberativa. De forma esquemática, o raciocínio pode ser decomposto em três etapas: i) a democracia pressupõe limites à deliberação majoritária, que não pode negar a premissa básica da igual dignidade dos envolvidos; e ii) em um mundo desencantado, tais limites não podem ser extraídos de nenhuma verdade revelada ou impostos verticalmente, o que seria incompatível com a igual dignidade; iii) é somente por meio da deliberação livre e no espaço

\footnotetext{
49 A possibilidade de desencontro entre a manifestação de vontade do corpo de representantes e dos representados é uma característica inerente à representatividade. Frank Michelman, Brennan and democracy, 2005, p. 15: "Democracy surely means that we do it by discussions leading up to votes in which everyone gets to participate on an equal footing with everyone else. But all real-world votes have losers, and none is ever decided by the sole and independent action of any individual. So the questions are: How is everyone to regard himself or herself as self-governing through social and institutional transactions from which many have dissented and in which in any event there is no real chance that any single person's own vote, or speech, or other considered political action decided the outcome? How is a person self-governing through institutional creation of laws that are revolting to him or her? (I'm sure you can think of some laws in force where you are that are revolting to you). Viewing matters from the standpoint of a concern about self-governing in politically decidable matters, this is what we may call the Institutional Difficulty"

$50 \quad$ O que não impede que o nível de participação popular no processo legislativo seja tomado como parâmetro para fundamentar maior ou menor autocontenção judicial. Nesse sentido, v. Gustavo Binenbojm e André Rodrigues Cyrino, "Parâmetros para a revisão judicial de diagnósticos e prognósticos regulatórios em matéria econômica". In: Daniel Sarmento, Cláudio Souza Neto e Gustavo Binenbojm, Vinte anos da Constituição Federal de 1988 (coords.), 2009, p. 759.
} 
público que se pode definir as condições constitutivas da democracia. Estas não são, portanto, fixas ou atemporais, devendo estar sujeitas à possibilidade permanente de crítica e revisão.

A partir dessa ideia básica, impõe-se uma nova forma de legitimação, dita discursiva ou deliberativa, que se coloca como complemento e/ou contraponto à legitimação puramente majoritária. $\mathrm{O}$ equilíbrio entre essas duas forças é produzido no próprio espaço público, por meio da interação das diferentes instâncias de discussão e decisão decorrentes de cada desenho institucional. Cada sociedade molda seu próprio sistema, que pode incluir instituições baseadas essencialmente na legitimação discursiva, com pouca ou nenhuma interferência formal das instâncias políticas. Não há gabarito fixo, nem deve haver, uma vez que a realidade é amplamente variável no tempo e no espaço. A Dinamarca do período nazista, com seu rei que teria ameaçado sair às ruas com a estrela de David para ajudar a proteger os judeus ${ }^{51}$, precisaria de menos intervenções contramajoritárias do que a Índia contemporânea, que embora tenha abolido formalmente o sistema de castas, ainda convive com a discriminação disseminada na prática social.

Em qualquer caso, porém, a verdade é que o equilíbrio entre forças majoritárias e contramajoritárias, em última instância, também caracteriza um equilíbrio deliberativo. Nem mesmo uma Constituição explícita poderia conter, para sempre, uma maioria insatisfeita e organizada. Muito menos um Poder Judiciário que tenha a pretensão de interpretar a ordem jurídica aberta sem nenhuma sintonia com as orientações políticas dominantes ${ }^{52}$. Os contextos de exceção logo demonstram essa circunstância. E devem servir também para que as situações de normalidade não obscureçam a existência de um equilíbrio real de poder. Dito de outra forma, a predominância eventual do direito ou de qualquer outro elemento só pode repousar num consenso das forças sociais, ainda que tácito. A peculiaridade - digna de elogio - da democracia deliberativa é a exigência de que qualquer equilíbrio seja justificado no espaço público sob a exigência da igual dignidade dos seus membros.

\footnotetext{
$51 \quad$ O rei era Christian X e há dúvidas sobre a veracidade da história. De qualquer forma, a lenda em torno da suposta promessa do rei se baseia nas muitas iniciativas corajosas do monarca e do povo dinamarquês na proteção e resgate da comunidade judaica local. Tais iniciativas, inclusive, ajudaram a fazer com que o uso obrigatório da Estrela de David nunca tenha sido introduzido no país.

52 A experiência norte-americana, baseada, desde a sua origem, no reconhecimento de força normativa à Constituição e na sua justiciabilidade, fornece vários exemplos de situações em que a Suprema Corte não teve força - ou não quis colocá-la à prova - em contextos politicamente difíceis. Um dos exemplos mais famosos ocorreu no caso Korematsu Vs. United States, no qual a Suprema Corte deixou de intervir para afastar o confinamento de cidadãos nipo-americanos, durante a segunda guerra mundial. Outro exemplo teria sido a timidez da Corte diante das perseguições políticas ocorridas durante o Macartismo. Sobre o tema, V. Stephen Griffin, American constitutionalism, 1998, p. 115.
} 
Nesse sentido, a jurisdição constitucional não é indispensável do ponto de vista lógico ou mesmo jurídico ${ }^{53}$. O que é indispensável, na democracia atual, é que nenhuma manifestação de poder seja imune às exigências da legitimação discursiva. Por isso se identificou a ocorrência de uma certa constitucionalização da política, que se vê obrigada a traduzir suas pretensões na linguagem mínima da Constituição. Esse conteúdo não precisa coincidir necessariamente com o catálogo de direitos fundamentais positivado em cada momento, já que não se pode banir do espaço público a discussão sobre a sua modificação, para mais ou para menos. Mesmo que a mudança proposta exija, em tese, nova manifestação do constituinte originário. Assim, a linguagem mínima dos direitos acaba sendo definida no interior do próprio processo político, de forma dinâmica ${ }^{54}$. O parâmetro - cujo controle é deliberativo, e não matemático - é a aceitação apenas de argumentos que não pressuponham ou impliquem a desqualificação da igual dignidade de $\operatorname{todos}^{55}$.

Uma possível crítica a ideia de constitucionalização da política seria o risco de que isso pode se converter em uma pasteurização da política, aumentando a insinceridade na deliberação. A objeção não procede. Em primeiro lugar, não se trata de uma imposição externa, mas sim de uma conseqüência da universalização das premissas da democracia substancial $^{56}$. É apenas natural que os políticos adotem em seu discurso os elementos mínimos

53 Nesse sentido, com base em densa fundamentação e exemplos concretos, v. Dieter Grimm, Jurisdição constitucional e democracia, Revista de Direito do Estado n ${ }^{\circ}$ 4, 2006, p. 9: “A jurisdição constitucional não é nem incompatível nem indispensável à democracia. (...) Por outro lado, há suficientes provas históricas de que um Estado democrático pode dispensar o controle judicial de constitucionalidade. As Constituições não estão condenadas a permanecer como meros tigres de papel se não houver órgãos especializados para garantir a sua aplicação. É que há menos exemplos dessa última afirmação do que da assertiva contrária, mas indubitavelmente existem exemplos neste sentido. Ninguém duvidaria do caráter democrático de Estados como Reino Unido e a Holanda, que não adotam o controle judicial de constitucionalidade. As razões para tal são variadas. De um lado, os governos democráticos dificilmente desdenharão dos limites que lhes são impostos pela Constituição. Particularmente, o processo político frequentemente funciona de acordo com as regras de organização e de procedimento fixadas na Constituição. De outro giro, as Cortes não são as únicas que podem fazer as vezes de guardiãs da Constituição. O controle interórgãos que emana da separação de Poderes também pode desempenhar tal função, assim como o apoio popular à Constituição ou um efetivo controle de mídia".

$54 \quad$ No Brasil atual seria provavelmente impensável defender na arena política um discurso discriminatório explícito ou evidente, como uma política de bloqueio a migrações internas. Mas certamente há espaço para discutir a flexibilização dos direitos trabalhistas contidos na Constituição, ainda que a eles se atribua status de fundamentalidade.

$55 \quad$ Rainer Forst procura sistematizar essas exigências mínimas sem recorrer a conteúdos em concreto, por meio dos conceitos de reciprocidade e generalidade. Reciprocidade significa que ninguém pode deduzir a pretensão a um direito ou bem sem aceitar a possibilidade de que outros tenham possibilidade de acesso ao mesmo. Exige ainda que a essa pretensão seja fundamentada publicamente, e não fixada de forma unilateral. Generalidade significa que todos devem ter a mesma chance de submeter suas pretensões e argumentos. A comunidade de justificação deve coincidir com o âmbito de validade da norma. Rainer Forst, Das Recht auf Rechtfertigung - Elemente einer konstruktivistischen Theorie der Gerechtigkeit, 2007, p. 249. Usando o primeiro desses elementos, é possível construir um exemplo de aplicação discursiva do parâmetro, envolvendo questão que se encontra na pauta de discussões do STF: nenhum grupo pode fundamentar o direito ao exercício de uma liberdade de orientação sexual sem reconhecer aos demais a possibilidade de igual direito.

56 De forma sintomática, mesmo teorias influentes que criticam a judicialização não defendem a desconstitucionalização do debate político, mas sim a mudança da sua sede principal, que deveria ser novamente 
da linguagem constitucional, até do ponto de vista estratégico. Em segundo lugar, a eventual insinceridade argumentativa deve ser denunciada no próprio espaço público, cabendo aos adversários expor as fragilidades e, deliberativamente, forçar determinado ponto de equilíbrio.

Essa constatação deve servir, igualmente, para afastar a objeção de que a democracia deliberativa pressupõe uma idealização romântica do cidadão médio, e mais ainda do processo político. É certamente desejável que os indivíduos sejam capazes e tenham interesse verdadeiro em um debate franco, marcado pela disposição sincera de ouvir o outro e eventualmente aderir a seus argumentos. Mas não é nesse elemento contingente que se está colocando a ênfase, mas sim na possibilidade de crítica pública e no equilíbrio deliberativo dela resultante. Nesses termos, o paradigma da democracia deliberativa e da política constitucional pode ser compatibilizado até mesmo com teorias que se baseiam na idealização negativa do processo político. É o caso das teorias ligadas ao movimento da public choice, que procuram explicar a política a partir do comportamento auto-interessado dos seus agentes $^{57}$. Mesmo sem concordar com esse reducionismo, é possível obter proveito das análises empíricas desenvolvidas no âmbito dessa linha de pesquisa e, o que é mais importante, concluir pela necessidade de um desenho institucional que minimize o risco de captura do Estado por interesses particulares. Mesmo no âmbito da public choice, aliás, essa é uma corrente de investigação influente ${ }^{58}$.

Numa postura um pouco menos cética, é até provável que, no médio ou longo prazo, a deliberação promova alguma dose de diálogo efetivo e amalgamento entre diferentes espectros políticos, facilitando acomodações e diluindo radicalismos ${ }^{59}$. Mesmo que não fosse assim, a necessidade de que as propostas coletivas sejam defendidas publicamente exige de seus defensores a capacidade de indicar alguma fundamentação racional e os expõe à crítica político-social, legitimando o processo decisório. Em outras palavras, a deliberação se

situada nas instâncias eleitas e no espaço público. Nesse sentido, v. Larry Kramer, The people themselves: popular constitutionalism and judicial review, 2004; e Mark Tushnet, Taking the Constitution away from the courts, 1999.

$57 \quad$ James Buchanan, Politics as public choice, 2000, p. 21. No mesmo sentido, confirmando que essa é a premissa básica da public choice, v. "Constitutional public choice”. In: Dennis C. Mueller (Ed.), Perspectives on public choice, 2005, p. 124.

Essa linha de estudo costuma ser identificada como economia constitucional, tendo James Buchanan como precursor e principal representante. Para uma visão abrangente do seu pensamento, confira-se a obra já citada, Politics as public choice, 2000. Um instigante estudo das instituições políticas brasileiras, sob a mesma perspectiva, encontra-se em Jorge Vianna Monteiro, Lições de economia constitucional, 2004.

Afirmando que a deliberação fora do espaço público tende a promover a polarização de interesses, pela natural aproximação de pessoas com ideias e inclinações semelhantes, que tendem a se reforçar mutuamente e desconsiderar a diversidade, v. Cass Sunstein, Designing democracies, 2001, pp. 7 e 14 e ss. 
justifica ainda quando funcione apenas como "vitrine" das decisões - e não como verdadeira instância decisória - para que sobre elas incida a crítica pública em bases mais abrangentes ${ }^{60}$.

Mesmo sob essa perspectiva cética, o Parlamento representa ainda o fórum público por excelência $^{61}$. Ainda que não se queira reconhecer nenhum mérito intrínseco ao corpo de parlamentares, lembre-se que é no parlamento que as oposições encontram um espaço institucional para se manifestar, estabelecendo um contraponto ao governo. Além disso, a discussão legislativa é, como regra, apta a produzir maior visibilidade do que o processo decisório administrativo - sobretudo quando se considera a Administração central - sem prejuízo da saudável democratização deste último ${ }^{62}$.

Como se vê, o estudo não pretende negar a preferência da decisão parlamentar sobre outras instâncias, sobretudo as que não sejam ocupadas por agentes eleitos. Nem haveria razão para imaginar que indivíduos isolados ou pequenos colegiados - como juízes e tribunais - fazem escolhas necessariamente melhores para a coletividade, como se tivessem acesso direto a uma suposta verdade. Ao contrário, o mais provável é que o embate direto entre os diferentes grupos sociais se beneficie do pluralismo de ideias e de expertises, além de submeter a teste eventuais preconceitos ou interesses particulares que podem afetar as decisões. O que se exige é que toda manifestação de poder leve em conta a necessidade de legitimação discursiva, que pode justificar a criação de processos decisórios que não se fundamentem na regra majoritária.

Por fim, veja-se que o dever de justificação tantas vezes mencionado não precisa se manifestar, necessariamente, sob a forma de uma motivação formal de cada uma das leis ou atos administrativos, embora a ideia seja promissora. O que importa é a possibilidade de

60 Dieter Grimm, Die Zukunf der Verfassung, 1991, pp. 357-358: “O ponto de partida é a percepção de que as decisões políticas mais do que produzidas no Parlamento, são nele apresentadas. Tal apresentação não se converte, contudo, em simples ritual, antes atua de volta na formação da opinião pública e, por outro lado, também na formação da vontade estatal, em caráter prospectivo. No Parlamento a maioria não está mais sob si mesma, tendo de expor e justificar publicamente seus propósitos, deixar que sejam comparados às alternativas propostas pelas minorias e afastar a crítica destas. O processo parlamentar possibilita assim a transparência da conduta governamental - a qual, por sua vez, é condição prévia para a crítica e o controle públicos continuados, a produção de ideias e a comunicação de interesses - e, sobretudo, abre oportunidades de participação para grupos que não dispõe de acesso institucionalizado ou informal ao poder. (...) Nessa função, apesar de todas as suas deficiências, o Parlamento ainda se apresenta, nos dias de hoje, como insubstituível por qualquer outra instituição" (Tradução livre).

61 Assim, afirmando que o Parlamento ainda reúne as melhores condições para a decisão democrática, a qual pressupõe um processo livre de formação da vontade estatal, desenvolvido com ampla publicidade e dotado de condições para que as diferentes visões de mundo sejam levadas em consideração, v. Konrad Hesse, Grundzüge des Verfassungsrechts der Bundesrepublik Deutschland, 1993, p. 57.

62 Sobre os mecanismos de democratização da Administração, tendo como pano de fundo a ideia de ascensão do espaço público, v. Rogério Gesta Leal, Esfera pública e participação social: possíveis dimensões jurídico-políticas dos direitos civis de participação social no âmbito da gestão dos interesses públicos no Brasil, Revista Brasileira de Direito Público, n 19, 2007, pp. 35-65 (especialmente a p. 53 e ss.). 
crítica permanente e desimpedida da esfera pública, em todos os seus elementos ${ }^{63}$. Isso não significa, naturalmente, que o debate público seja incompatível com qualquer limitação, mas apenas que as próprias limitações devem estar sujeitas a debate. Isso inclui eventuais limitações impostas por decisão contramajoritária e com pretensão formal de definitividade, na linha da argumentação desenvolvida acima. A título de exemplo, tome-se a decisão do STF no caso Ellwanger, vedando o discurso racista anti-semita.

Essa última questão - limites à decisão e à própria deliberação majoritária - evoca o tema da legitimidade da jurisdição constitucional.

\section{b) A legitimidade da jurisdição constitucional}

Assentada a conclusão de que o elemento central da democracia deliberativa é a submissão de todas as instâncias de poder à exigência de legitimação discursiva, não seria inconcebível a ideia de suprimir instâncias formais de controle, sobretudo aquelas que sejam ocupadas por agentes não-eleitos. Em tese, o próprio debate público poderia se encarregar de gerar o equilíbrio deliberativo referido acima. Essa é, portanto, uma questão de desenho institucional, e não de obviedade. No entanto, a proliferação da jurisdição constitucional sugere que o modelo pode apresentar pontos fortes. Essa é justamente a conclusão a que se vai chegar, pelos fundamentos abaixo.

Em primeiro lugar, há uma evidente vantagem na existência de uma instância de controle das condições substantivas da democracia, formalmente separada do processo decisório original. A obrigação de analisar as questões e de fundamentar as decisões por esse ângulo cria uma instância reflexiva, sobretudo quando se permita que a sociedade civil suscite o controle. Lembre-se que as minorias nunca perdem seu status de igualdade e que a legitimação discursiva complementa a decisão majoritária. Parece desejável, portanto, que haja um canal para que a sociedade possa irritar o processo decisório e forçar manifestações específicas sobre o atendimento às condições democráticas, depuradas de considerações mais

\footnotetext{
63 O termo esfera pública está sendo empregado para designar as instâncias formais de representação e também o chamado espaço público, em sentido mais estrito, entendido como um domínio não-oficial e nãohierarquizado, que acaba exercendo um controle difuso, mas permanente, sobre as decisões produzidas e sobre a própria pauta dos canais oficiais. Isso não inclui apenas manifestações ostensivas, como passeatas, mas também espaços da vida comum em que a formação da opinião pública ocorre, como os locais de trabalho e as universidades. V. Jürgen Habermas, Faktizität und Geltung - Beiträge zur Diskurstheorie des Rechts und des demokratischen Rechtsstaats, 1998, p. 435. Sob perspectiva diversa, mas também reconhecendo a necessidade de canais não oficiais de deliberação, municiados por fontes de informação também não oficiais, v. Robert Dahl, On democracy, 2000, p. 97. Ainda sobre o tema, reconhecendo que o pluralismo não pode ser apenas ético, mas também de esferas sociais onde a discussão ocorre, v. Rainer Forst, Das Recht auf Rechtfertigung - Elemente einer konstruktivistischen Theorie der Gerechtigkeit, 2007, p. 259.
} 
gerais sobre a conveniência e oportunidade das políticas públicas. Tal possibilidade pode ser vista, inclusive, como uma forma de democracia participativa ${ }^{64}$. Ademais, a textura aberta do direito faz com que a sua criação e aplicação sejam processos interligados e dinâmicos, de modo que essa instância reflexiva pode abrir espaço para considerações surgidas após a entrada em vigor de determinado ato do Poder Público ${ }^{65}$.

Veja-se que não se falou, ainda, em jurisdição constitucional. Em tese, a instância de controle referida acima pode assumir feições diversas. Poderia até, como cogita Habermas, ser instalada no interior do Poder Legislativo, talvez na forma de uma comissão ${ }^{66}$. Apesar disso, há muitos fatores que recomendam a introdução de um controle judicial, como se passa a expor. No Brasil, embora o próprio controle de constitucionalidade tenha previsão constitucional expressa, tais considerações nem por isso se tornam irrelevantes, uma vez que os tribunais, especialmente o STF, têm adotado uma postura proativa que exige justificação no espaço público.

O Poder Judiciário, ao contrário de uma possível comissão parlamentar, deve estar fora da política partidária. Trata-se, portanto, de uma instância neutra em relação às forças políticas, que, inevitavelmente, estão comprometidas em diferentes níveis com a defesa de um determinado grupo de interesses ${ }^{67}$. Na política, os acordos são inevitáveis e podem gerar acomodações estratégicas, ainda que haja exigências mínimas e controle público. Do Judiciário se pode cobrar que decida sem esse tipo de vinculação, tratando cada caso como

64 Gisele Cittadino, Judicialização da política, constitucionalismo democrático e separação dos Poderes. In: Luiz Werneck Vianna, A democracia e os três Poderes no Brasil, 2002, p. 31: "É, portanto, pela via da participação jurídico-política, aqui traduzida como o alargamento do círculo de intérpretes da Constituição, que se processa a interligação dos direitos fundamentais e da democracia participativa. Em outras palavras, a abertura constitucional permite que cidadãos, partidos políticos, associações, etc. integrem o círculo de intérpretes da Constituição, democratizando o processo interpretativo - na medida em que se ele se torna aberto e público - e, ao mesmo tempo, concretizando a Constituição". No mesmo sentido, Anabelle Macedo Silva, Concretizando a Constituição, 2005, p. 139: "Outrossim, o povo não é apenas fonte ativa de legitimidade democrática através das eleições, também o é quando utiliza as demais vias de participação na vontade estatal, por exemplo quando demanda na via jurisdicional a concretização dos direitos fundamentais". V., ainda, a obra clássica de Peter Häberle, Hermenêutica constitucional: a sociedade aberta dos intérpretes da constituição, 1997, na qual se defende uma dimensão mais ampla de abertura democrática do processo interpretativo, nãocircunscrita à participação nos processos formais de decisão.

65 De certa forma, a existência de um mecanismo formal de controle transforma a legislação em um processo dinâmico, que pode ser aberto à participação direta da sociedade civil por meio da provocação. Nessa linha, v. Alec Stone Sweet, Governing with judges - Constitutional politics in Europe, 2000, p. 21.

66 Jürgen Habermas, Faktizität und Geltung - Beiträge zur Diskurstheorie des Rechts und des demokratischen Rechtsstaats, 1998, p. 295. O autor suscita a ideia de que um órgão desse tipo no interior do Parlamento, que criaria uma diferenciação institucional entre legislação e controle, aumentaria a racionalidade da discussão parlamentar e forçaria a deliberação sobre questões que muitas vezes permanecem indefinidas por força de compromissos.

$67 \quad$ Neutralidade judicial não significa que as decisões judiciais sejam destituídas de conteúdo decisório ou que os juízes sejam cristais, imunes à influência externa ou mesmo de suas pré-compreensões. Sobre a neutralidade judicial possível, v. Luís Roberto Barroso, Interpretação e aplicação da Constituição, 2009, p. 288 e ss. 
uma exigência autônoma de aplicação adequada da ordem jurídica ${ }^{68}$. Não se está negando a possibilidade do desvio; apenas afirmando que "acordos políticos" constituem propriamente um desvio na função jurisdicional - para o qual deve estar atenta a crítica pública - e não uma circunstância normal da sua lógica de atuação. O que pode existir legitimamente é preocupação com a coerência valorativa entre decisões diversas, mas essa é uma exigência de ordem normativa, e não uma acomodação auto-interessada.

Além de não poder estar vinculado às correntes políticas, o Judiciário é relativamente desarmado das armas políticas. Não pode fazer campanha de mídia, comício, ou populismo assistencialista. Pelo menos não em tese, ainda que o controle, uma vez mais, resida no espaço público. Na mesma linha, está sujeito a alguma dose de influência dos outros Poderes, inclusive por meio de reformas legislativas que afetem a estrutura judicial e do processo. Adicionalmente, o juiz está submetido a uma exigência argumentativa muito mais intensa do que os agentes políticos ${ }^{69}$, devendo se limitar aos argumentos de razão pública ${ }^{70}$. Ainda que a política tenha se constitucionalizado em parte, não é possível comparar suas constrições às do processo judicial. Até porque o sistema político detém a prerrogativa de alterar as leis e, em última instância, a própria Constituição, ditando as balizas da decisão judicial ${ }^{71}$.

68 A ideia tradicional de que o Estado juiz é equidistante em relação às partes continua sendo o núcleo da neutralidade, fundamento da legitimação judicial. A neutralidade "arrisca" sua reputação a cada julgado, já que pelo menos uma das partes pode ficar insatisfeita e questionar a isenção do juiz. No plano geral, porém, é difícil imaginar que um sistema judicial possa se manter a longo prazo caso haja uma percepção generalizada de que foi capturado. Nesse sentido, v. Alec Stone Sweet, Governing with judges - Constitutional politics in Europe, 2000, p. 16.

69 Ana Paula de Barcellos, Ponderação, racionalidade e atividade jurisdicional, 2005, pp. 39-40.

$70 \quad$ John Rawls, Liberalismo político, 1996, pp.224-5: "Los magistrados de la Suprema Corte no pueden, por supuesto, invocar su propia moral, ni los ideales y virtudes de la moralidad em general. Deberán considerar esos valores e ideales ajenos al caso constitucional. De igual manera, tampoco pueden invocar sus puntos de vista religiosos o filosóficos ni los de otras personas. Tampoco pueden citar irresctrictamente los valores políticos. Em cambio, deben recurrir a los valores políticos que em su opinión pertenecen a la comprensión más razonable de la concepción pública de la justicia, y a sus valores políticos de justicia y de razón pública. Éstos son los valores em los que creen de buena fé, como lo exige el deber de civilidad, y que se espera que suscriban todos los ciudadanos en tanto que personas razonables y racionales".

71 José Eduardo Faria, Política, sistema jurídico e decisão judicial, 2002, pp. 48-9: “A 'independência do juiz' jamais pode ser entendida com 'absoluta', ou seja, o Judiciário não é um Poder distante, oposto e contraditório em relação aos demais Poderes do Estado. A magistratura integra o sistema político e não pode ser examinada à margem dos parâmetros institucionais de relacionamento entre um dos Poderes do Estado (que é o seu caso) e os demais. Assim a criatividade judicial (do mesmo modo que a independência e a imparcialidade) deve ser examinada nestes limites. Se, nos chamados 'casos difíceis', o juiz é obrigado a fazer escolhas políticas - muitas vezes por delegação do próprio legislador - essa criatividade é exercida nos limites da legitimidade legal-racional. O legislador pode rever a delegação ou fixar a opção política. Entretanto, até que isso aconteça, a determinação de uma linha política por parte do juiz - desde que em conformidade com os valores fundamentais positivados pelo ordenamento - não significa, necessariamente, um comportamento antidemocrático, contrário à divisão de poderes ou ofensivo ao Estado de Direito". 
É certo que o controle de constitucionalidade pode operar como barreira de contenção dessa prerrogativa ${ }^{72}$, mas não totalmente ou por tempo indeterminado. No Brasil, essa questão assume um colorido especial em razão da abrangência e do detalhismo do texto constitucional, que confere ao Judiciário a oportunidade - e, em certo sentido - o dever de afastar uma série de decisões políticas que, materialmente, pouco tem a ver com as condições democráticas. Essa culpa, porém, não é do Judiciário. Nem seria desejável que os juízes adotassem uma postura de aplicação seletiva da Constituição, criando normas constitucionais de primeira e de segunda classe, o que acabaria minando a força normativa do documento como um todo, substituída pelo voluntarismo judicial ${ }^{73}$. Como consolo, fica o lembrete de que a Constituição não é imutável - as 58 emendas da Constituição brasileira que o digam - ou insubstituível. Assim, a própria manutenção do texto constitucional não é uma decisão alheia ao equilíbrio deliberativo existente no presente e a cada momento. Enquanto o texto estiver em vigor, cabe ao Judiciário cumprir seu papel de forma altiva, mas também permeável ao diálogo com os demais Poderes.

Por tudo quanto foi exposto, situar no Judiciário a palavra provisoriamente final pode ajudar a forçar um equilíbrio verdadeiramente deliberativo, e não pela força. Como se viu, a existência, extensão e legitimidade desse controle são influenciadas de forma determinante pelo desenho institucional e devem estar permanentes abertos à crítica e revisão. Com essas ressalvas, não parece ingênuo afirmar que a jurisdição constitucional tende a contribuir para aumentar a qualidade geral do debate público, evitando que argumentos de princípio sejam desconsiderados ou subestimados ${ }^{74}$. A última parte do estudo será dedicada a aprofundar a analise da posição do Judiciário no equilíbrio deliberativo, especialmente no Brasil.

72 V. Dieter Grimm, Jurisdição constitucional e democracia, Revista de Direito do Estado n ${ }^{\circ}$ 4, 2006, p 16; e Alec Stone Sweet, Governing with judges - Constitutional politics in Europe, 2000, p. 24-5.

73 Parece ser essa a motivação de Carlos Santiago Nino quando admite o controle de constitucionalidade para preservar a Constituição histórica (um dos três casos em que o valor epistêmico da decisão deliberativa seria enfraquecido e poderia ser suplantado pela jurisdição constitucional). V. La Constitución de la democracia deliberativa, 1997, p. 281: “Consideremos el caso en el que la decisión democrática infringe en forma clara el texto, que es el aspecto más saliente de la convención de acuerdo a las reglas tradicionales de interpretación. La decisión democrática puede ser impecable desde el punto de vista de los elementos del constitucionalismo liberal y participativo, pero ésta podría estar en contra del elemento que preserva el estado de derecho. Aunque no se vea violado ningún derecho, si si mantuviera la decisión democrática, la práctica social constituida por la constitución histórica podría verse debilitada y, como resultado de ello, la eficacia de las decisiones democráticas podría resultar enormemente afectada. En esta situación el juez puede intervenir en forma justificada para invalidar la ley democrática a fin de proteger la convención constitucional que garantiza la eficacia de las decisiones democráticas mismas". As duas outras hipóteses em que Nino admite o controle seriam a preservação do procedimento democrático e a proteção de um espaço de autonomia moral de cada indivíduo contra investidas perfeccionistas de eventuais maiorias.

Ronald Dworkin, Freedom's law - The moral reading of the American Constitution, 1996, p. 345: "When an issue is seen as constitutional, however, and as one that will ultimately be resolved by courts applying general constitutional principles, the quality of public argument is often improved, because the argument concentrates from the start on questions of political morality. Legislators often feel compelled to argue for the 


\section{O equilíbrio deliberativo entre ativismo e autocontenção}

O Judiciário é o novo protagonista, tendo seu papel decisório ampliado pela substantivação da democracia e pela revalorização da razão prática. De forma particular, o Judiciário é o Poder que tem maiores condições de influir no próprio desenho institucional do Estado, delimitando as competências constitucionais dos três Poderes. No Brasil, com uma constitucionalização ampla e diversas modalidades de controle de constitucionalidade, é difícil imaginar uma questão que não possa ser efetivamente judicializada. Ainda mais com tantos legitimados ávidos por provocar o controle, inclusive em razão dos gargalos do sistema político. Tantas novas possibilidades exigem uma boa dose de cautela para que não se confirme o temor de uma supremocracia ${ }^{75}$.

Assim, ainda que haja espaço para ativismo pontual em diversas questões específicas, a regra deve ser a autocontenção. Isso significa, em primeiro lugar, levar a sério a presunção de constitucionalidade dos atos praticados pelas autoridades competentes de outros Poderes. O juízo de inconstitucionalidade não pode ser deturpado em juízo de inconveniência, uma vez que não cabe ao Judiciário escolher dentre as opções possíveis, mas sim excluir as inaceitáveis ${ }^{76}$. Em se tratando da avaliação de realidades técnicas complexas ou sujeitas à

constitutionality and not just the popularity of measures they support, and Presidents or governors who veto a law cite constitutional arguments to justify their decisions. When a constitutional issue has been decided by the Supreme Court, and is important enough so that it can be expected to be elaborated, expanded, contracted, or even reversed, by future decisions, a sustained national debate begins, in the newspapers and other media, in law schools and classrooms, in the public meetings and around dinner tables. That debate better matches Hand's conception of republican government, in its emphasis on matters of principle, than almost anything the legislative process on its own is likely to produce".

75 Oscar Vilhena Vieira, Supremocracia. In: Daniel Sarmento (coord.), Filosofia e teoria constitucional contemporânea, 2009, pp. 483-502.

76 Não cabe a juízes e tribunais impor o que lhes pareça ser a melhor escolha, mas sim barrar opções inválidas e garantir desde logo direitos que não estejam à disposição das maiorias. Nesse sentido, v. Aharon Barak, The judge in a democracy, 2006, p. 248: "When the executive authority exercises its power reasonably, it operates within its authority and the judge will not intervene. This is true even if the judge, had the executive authority been granted to him, would have used the power in a different reasonable way. There is no room for judicial intervention if the exercise of executive authority lies within the zone of reasonableness. The court must refrain from imposing its own references regarding implementation onto the society in which it operates". Valendo-se de argumentação mais analítica, Laura Clérico afirma que afastar uma decisão administrativa sob argumento de que haveria outra melhor significaria exercer um juízo forte de adequação. Para ser consistente, tal juízo exigiria que todos os possíveis argumentos relevantes pudessem ser analisados pelo juiz. Isso seria, no mínimo, pretensioso. V. Laura Clérico, Die Struktur der Verhältnismäßigkeit, 2001, p. 41. Na mesma linha, v. Humberto Ávila, Teoria dos princípios, 2003, pp. 108-113. 
deflagração de efeitos sistêmicos imprevisíveis ${ }^{77}$, a autocontenção deve ser reforçada em favor das decisões produzidas por instância dotada de maior capacidade institucional ${ }^{78}$. Nesses casos, a intervenção judicial deve se tornar menos pretensiosa ${ }^{79}$, podendo se aproximar de um controle da racionalidade do ato ${ }^{80}$.

Como regra, o controle do equilíbrio entre autocontenção e ativismo ocorre de forma difusa, por meio da crítica no espaço público. Nesse sentido, deve-se estimular o debate amplo não apenas em relação ao mérito das decisões, mas também em relação aos argumentos empregados. A crítica pública - da população, da imprensa, da doutrina jurídica ou mesmo dos membros de outro Poder - não pode ser tratada como desrespeito. Ao contrário, a tendência é que se torne mais frequente, em resposta ao crescimento da interferência judicial $^{81}$. E espera-se que cresça também em qualidade, alcançando o nível de sofisticação das análises econômicas e políticas comumente divulgadas nos meios de comunicação.

77 Gustavo Amaral, Direito, escassez e escolha, 2001, p. 38: “O judiciário está aparelhado para decidir casos concretos, lides específicas que lhe são postas. Trata ele, portanto, da microjustiça, da justiça do caso concreto". No mesmo sentido, demonstrando que toda a estrutura jurídica foi concebida e ainda se encontra organizada para a proteção de direitos individuais, mas reconhecendo a necessidade de adaptações, v. José Reinaldo de Lima Lopes, "Direito subjetivo e direitos sociais: o dilema do Judiciário no Estado Social de Direito". In: José Eduardo Faria (org), Direitos humanos, direitos sociais e justiça, 2005, pp. 113-143

78 Sobre capacidades institucionais e judicialização, com ênfase em sua aplicação ao Judiciário, v. Daniel Sarmento, "Interpretação constitucional, pré-compreensões e capacidades institucionais do intérprete". In: Daniel Sarmento, Cláudio Souza Neto e Gustavo Binenbojm, Vinte anos da Constituição Federal de 1988 (coords.), 2009; e Luis Roberto Barroso. Judicialização, ativismo judicial e legitimidade democrática, Revista de Direito do Estado $\mathrm{n}^{\circ}$ 13, 2009, p. 82. Embora não esse não seja um desenvolvimento necessário, o conceito de capacidades institucionais pode ser empregado para defender que as decisões judiciais se orientam pelo formalismo jurídico, abstendo-se de invalidar atos de outros Poderes a menos que haja violação manifesta de comando legal. Nesse sentido, v. Adrian Vermeule, Judging under uncertainty, 2006, p. 289: (...) The institutionalist dilemma is that their choices must rest upon institutional variables, but the information needed to fill in the values of these variables does not yet exist. I suggested that judges acting in these circumstances must fall back upon a repertoire of techniques for decisionmaking under uncertainty. Those techniques counsel judges to adopt an unassuming posture of rule-bound, relatively inflexible decisionmaking, using a small set of interpretive tools and deferring to agencies and legislatures where texts are anything less than clear and specific". 79 Para uma série de parâmetros destinados a graduar a intervenção judicial em matéria regulatória, v. Gustavo Binenbojm e André Rodrigues Cyrino, "Parâmetros para a revisão judicial de diagnósticos e prognósticos regulatórios em matéria econômica”. In: Daniel Sarmento, Cláudio Souza Neto e Gustavo Binenbojm, Vinte anos da Constituição Federal de 1988 (coords.), 2009, p. 758-60.

80 Gustavo Binenbojm, Uma teoria do direito administrativo, 2006, p. 227: “Com efeito, naqueles campos em que, por sua alta complexidade técnica e dinâmica específica, falecem parâmetros objetivos para uma atuação segura do Poder Judiciário, a intensidade do controle deverá ser tendencialmente menor. Nesses casos, a expertise e a experiência dos órgãos e entidades da Administração em determinada matéria poderão ser decisivas na definição da espessura do controle". Para uma aplicação judicial dessa linha de raciocínio, v. STJ, DJU 14 jun. 2004, REsp 572.070/PR, Rel. Min. João Otávio de Noronha: “A delimitação da chamada "área local" para fins de configuração do serviço local de telefonia e cobrança da tarifa respectiva leva em conta critérios de natureza predominantemente técnica, não necessariamente vinculados à divisão político-geográfica do município. (...) 3. Ao adentrar no mérito das normas e procedimentos regulatórios que inspiraram a atual configuração das 'áreas locais' estará o Poder Judiciário invadindo seara alheia na qual não deve se imiscuir”.

$81 \quad$ Como destaca Luís Roberto Barroso, o debate de certos temas no STF tem obtido maior repercussão do que a discussão correspondente no Poder Legislativo, como ocorreu na ação direta em que se declarou a constitucionalidade das pesquisas com células-tronco embrionárias. Isso pode até indicar que a população e a mídia já estão percebendo - talvez ainda sem consciência crítica - que uma decisão constitucional tem a pretensão de se situar em um plano diferente daquele ocupado pela legislação infraconstitucional, subordinando- 
Para além desse controle difuso, não se exclui, taxativamente, a possibilidade de que o sistema político estabeleça constrições ao processo judicial ou a determinadas formas de decisão. A validade de tais interferências deve ser investigada caso a caso. As leis que regulam as ações diretas no STF instituíram a possibilidade de audiências públicas, a critério do relator. Não seria inconstitucional, e.g., impor a realização do procedimento em situação de especial relevância, como os casos em que o Tribunal acene com a intenção de declarar a inconstitucionalidade de emenda constitucional ${ }^{82}$. De certa forma, a Lei $n^{\circ}$ 9.868/99 impôs uma limitação ainda mais intensa, ao exigir quórum qualificado para que o STF faça a modulação temporal de suas decisões. Não deixa de ser uma forma de constrição a um juízo que, embora encerre uma ponderação de valores constitucionais, apresenta também grande potencial para suscitar avaliações de natureza política ${ }^{83}$. Exigências desse tipo devem ser analisadas com especial cautela, uma vez que podem ser visualizadas como limitações ao exercício da função jurisdicional por decisão política de outro Poder. Ainda assim, não se descarta que propostas do gênero possam ser discutidas no espaço público ${ }^{84}$.

a. V. Luis Roberto Barroso. Judicialização, ativismo judicial e legitimidade democrática, Revista de Direito do Estado ${ }^{\circ} 13,2009$, p. 78.

82 Cláudio Ari Mello, Democracia constitucional e direitos fundamentais, 2004, p. 193: "À margem das virtudes democráticas já naturais ao processo judicial, a jurisdição constitucional opera na linha de fronteira entre Direito e política, e portanto o seu funcionamento está exposto a exigências mais intensas no que se refere à democratização formal dos seus procedimentos".

83 O argumento de que o quórum qualificado para modulação temporal poderia ser entendido como um limite imposto a essa modalidade específica de raciocínio ponderativo foi inicialmente levantado por Luís Roberto Barroso, O controle de constitucionalidade no Direito brasileiro, 2008, p. 200: "A propósito do art. 27 da Lei n. 9.868/99, é possível, ainda, proceder a uma leitura singular, porém bastante razoável, do dispositivo. Dele se pode extrair um caráter limitador da competência do Supremo Tribunal Federal para restringir os efeitos retroativos da decisão de inconstitucionalidade. De fato, para que a Corte possa decidir a ponderação de valores em favor da proteção dos efeitos da norma declarada inconstitucional - negando, assim, eficácia $e x$ tunc à decisão -, passou a ser necessário o quórum de dois terços de seus membros ${ }^{171}$. À vista dessa interpretação, coloca-se a questão da legitimidade ou não de o legislador infraconstitucional estabelecer uma preferência abstrata em favor de um dos valores constitucionais em disputa. O dispositivo, a bem da verdade, tem sido utilizado com cautela e parcimônia". O autor avalia ainda que, embora seja objeto de ação direta de inconstitucionalidade ainda pendente de julgamento, a exigência já se incorporou à prática do STF e dificilmente será afastada.

${ }_{84}$ Nessa linha, Adrian Vermeule e Jacob Gersen cogitam a possibilidade de se converter regras de prudência judicial em regras institucionais. De forma específica, defendem a conversão do Chevron test - pelo qual os tribunais devem ser deferentes às decisões regulatórias que sejam razoáveis e não violem claramente normas jurídicas superiores - em uma regra de votação, pela qual se exigiria maioria qualificada para que o Judiciário possa derrubar a decisão administrativa. Segundo eles, a regra de prudência impõe uma operação mental complexa, obrigando o juiz a tentar separar o que seria razoável da sua avaliação pessoal sobre a resposta (mais) correta. $\mathrm{O}$ controle intersubjetivo ficaria igualmente prejudicando, fazendo com que a deferência possa ser apenas retórica. A exigência de quórum qualificado dispensaria essas sutilezas e transformaria a deferência em uma propriedade objetiva da decisão. Com efeito, a existência de determinado número de votos em favor do ato, ainda que minoritários, seria suficiente para determinar a sua preservação. Sem prejuízo da racionalidade da proposta, é possível dizer que ela poderia produzir o efeito inverso se aplicada a colegiados muito homogêneos. De qualquer forma, vale o registro de que o próprio autor identifica possíveis inconvenientes associados à proposta - como a possibilidade de acomodações estratégicas no interior dos tribunais. Reconhece também que a ordem constitucional pode vedar esse tipo de modificação em determinados ambientes decisórios. V. Jacob 
É possível ainda que a decisão judicial produza respostas institucionais de outro Poder, o que tampouco deve ser necessariamente encarado como afronta ou invasão de competência. A democracia deliberativa exige argumentos porque não reconhece a ninguém a prerrogativa de impor à coletividade uma verdade revelada. Isso inclui os juízes, que devem estar abertos ao diálogo institucional ${ }^{85}$. De forma particular, o Judiciário não deve tratar cada aspecto de suas decisões como um imperativo constitucional acabado. Para além da afirmação de conteúdos constitucionais mínimos - ainda assim sujeitos à revisão por emenda ou por mudança de orientação jurisprudencial -, as decisões podem conter também desenvolvimentos possíveis, porém não necessários, da ordem constitucional. E o Tribunal deve ter a humildade de devolver esses espaços à decisão majoritária, quando reclamados por meio da edição de lei ou ato razoável ${ }^{86}$.

Essa cautela é especialmente importante no controle das omissões inconstitucionais, que não deve se converter em uma forma de ocupação excludente da esfera deliberativa. Não há lugar para a lógica do "quem chegar primeiro, leva”. Muito menos quando o primeiro a chegar seja o juiz. Com essa ressalva, a omissão inconstitucional dos agentes eleitos pode legitimar maior ativismo por parte do Judiciário, já que a liberdade de conformação atribuída aos primeiros não deve sobrepor-se total e indefinidamente a um dever constitucionalmente imposto $^{87}$. A decisão judicial pode quebrar a inércia em favor de alguma modalidade de

Gersen e Adrian Vermeule, Chevron as a voting rule, 116 Yale Law Journal, 676, 2006. Disponível em: http://papers.ssrn.com/sol3/papers.cfm?abstract_id=906633.

85 Sobre o ponto, destacando que a atividade jurisdicional estabelece naturalmente um diálogo com o Poder Legislativo, uma vez que a interpretação judicial acerca de determinado ato normativo - incluindo a declaração de sua inconstitucionalidade - "devolve" a questão ao legislador, que pode efetuar ajustes ou mesmo reformular o sistema, v. Aharon Barak, The judge in a democracy, 2006, p. 236 e ss. No mesmo sentido, destacando que o processo judicial permite a inclusão dos litigantes no diálogo, v. Alec Stone Sweet, Governing with judges - Constitutional politics in Europe, 2000, p. 21.

86 Essa linha auto-contida é o oposto do que fez o STF na ADIn 2797/DF, na qual declarou a inconstitucionalidade da lei que pretendia restabelecer o entendimento de que o foro por prerrogativa de função se mantém em relação aos atos praticados no exercício de função pública, mesmo após o fim da investidura. Como se sabe, essa era a orientação original do próprio STF, expressa na Súmula 394, que veio a ser cancelada pela Corte. Diante da tentativa do legislador de optar pela linha interpretativa inicial, o STF identificou taxativamente a ocorrência de usurpação de sua função como intérprete final da Constituição. Sequer cogitou, portanto, da possibilidade de que, diante de eventual pluralidade de opções interpretativas, caberia ao legislador a palavra final, ainda que superando a opção inicialmente adotada pela Corte no espaço aberto decorrente da ausência de manifestação majoritária. A mesma crítica é encontrada em Daniel Sarmento, "O neoconstitucionalismo no Brasil: riscos e possibilidades". In: Daniel Sarmento (coord.), Filosofia e teoria constitucional contemporânea, 2009, p. 138.

87 STF, MI 670/ES, DJ 06.11.2007, Rel. Min. Maurício Corrêa. No sentido aqui defendido, entendendo que a omissão das instâncias políticas autoriza medidas que, de outra forma, não seriam admissíveis por conta da separação dos Poderes, v. Luís Roberto Barroso, O controle de constitucionalidade no Direito brasileiro, 2008, pp. 142-143: "Em segundo lugar, veja-se que os poderes constituídos em geral, incluindo o legislador, estão submetidos à Constituição. No caso, o principal fator de legitimação da atuação do Judiciário é a omissão de outro Poder, que tinha como efeito a paralisação da eficácia de normas constitucionais. O provimento do 
concretização da pauta constitucional, sem prejuízo de que o Poder omisso venha a se manifestar e imprima nova orientação na matéria. Nesse sentido, é possível enxergar uma circunstância privilegiada para que se instaure um diálogo constitucional entre as instâncias judiciais e o sistema político. Isso não significa que o preenchimento provisório da lacuna será possível em todos os casos ou deva ocorrer sempre na mesma extensão. A natureza da norma faltante e a possibilidade de se extrair parâmetros normativos da própria ordem jurídica são elementos que devem ser sopesados para graduar a intervenção judicial legítima ${ }^{88}$.

Além dos mecanismos citados de controle das decisões judiciais em sentido amplo, não se pode descartar a possibilidade de intervenção do sistema político na própria estrutura e organização dos tribunais. Isso envolve escolhas que afetam intensamente o desenho institucional. Uma medida muitas vezes cogitada é a introdução da investidura por mandato fixo para os ministros do STF, o que permitiria maior oxigenação da Corte, além de evitar que, por fatores aleatórios, visões de mundo superadas possam se entrincheirar no Tribunal por tempo indeterminado. Outra ideia, na mesma linha, seria o sistema de indicação por origens múltiplas, de forma direta ou combinada (formação de listas). O poder de indicação/escolha poderia recair, e.g., no Presidente da República, no bloco majoritário e no bloco minoritário do Congresso Nacional, no próprio Tribunal e até nas universidades. Também aqui, o objetivo é aumentar a qualidade da deliberação, o que não deve abrir caminho para a partidarização da Corte.

Ainda em relação a limitações de procedimento, um aspecto pontual que merece atenção é o controle de pauta por parte da direção dos tribunais e o pedido de vista por parte dos magistrados, mecanismos que podem ser utilizados como forma de impedir a deliberação ou como artifício para esperar momentos favoráveis a determinado interesse. Esse tipo de atuação estratégica - muitas vezes individual - não deve ficar imune à crítica pública. Uma

mandado de injunção serve justamente para evitar a eternização dessa situação de desrespeito à força normativa da Constituição. Finalmente, veja-se que a adoção de um regime temporário não impede a atuação superveniente do Poder omisso, que pode abandonar a inércia e dar ao tema tratamento específico, afastando o regime que haja sido instituído pelo Judiciário". Na mesma linha, entendendo que a inércia das instâncias políticas autoriza maior ativismo judicial, v. José Marinho Paulo Junior, O poder jurisdicional de administrar - criação judicial de órgão administrativo, 2007, p. 90.

88 Não se sustenta, portanto, a tese de que a omissão inconstitucional autorize a corte constitucional a funcionar propriamente como legislador substituto, defendida por alguns autores, como Otto Bachof. Pelo menos não em todos os casos e nunca com verdadeira liberdade de conformação, especialmente quando o preenchimento da lacuna pressuponha mais decisão política livre do que construção jurídica razoável. Nesse mesmo sentido, v. Francisco Fernandez Segado, La justicia constitucional: uma visión de derecho comparado, tomo I, 2009, p. 639-46. O autor discorre, ainda, de forma analítica, sobre o tratamento das omissões inconstitucionais em diversos países, destacando a utilização de sentenças de natureza aditiva em muitos deles. No Brasil, tratando a possibilidade de preenchimento da lacuna como legislação substituta, sem prejuízo da preferência por soluções menos radicais, v. Walther Claudius Rothemburg, "Omissão inconstitucional e troca de sujeito”. In: André Ramos Tavares, Justiça constitucional - pressupostos teóricos e análises concretas, 2007, pp. 301-17. 
forma de controle, em relação aos pedidos de vista, poderia ser a exigência de que, após determinado prazo, o magistrado tenha de justificar em Plenário a eventual necessidade ou mesmo conveniência de prorrogação. A despeito da natureza pontual dessas observações, o que se quer destacar é que o modelo atual não decorre da natureza das coisas e pode ser aprimorado. E que eventuais propostas que surjam de fora para dentro não devem ser descartadas de plano sob a acusação de interferência indevida.

\section{Ativismo do bom e do ruim: fidelidade partidária e monopólio postal}

Por fim, com o objetivo de ilustrar algumas das conclusões teóricas desenvolvidas - e de exercitar a crítica pública defendida acima -, passa-se ao comentário sobre alguns aspectos de dois exemplos de ativismo judicial por parte do STF, sendo um deles valorado de forma positiva, e o outro negativamente. O primeiro caso é a decisão, em mandado de segurança, que determinou a perda de mandato parlamentar por troca injustificada de partido ${ }^{89}$. Embora a decisão seja reconhecidamente um dos pontos altos do ativismo no Brasil - pela inovação que introduziu na ordem jurídica, afetando intensamente o Poder Legislativo e o processo eleitoral - há um elemento de ordem constitucional que minimiza eventuais acusações de voluntarismo. E isso é mais importante do que a avaliação política eventualmente favorável que se possa fazer acerca da novidade. Além disso, a decisão abre espaço para amplo diálogo institucional com o legislador, como se passa a demonstrar.

Na sua conclusão essencial - perda do mandato - a decisão do STF não se apresenta como uma escolha entre diferentes opções políticas, mas sim como imposição de princípios constitucionais que suportam a medida. E, mais importante, de princípios constitucionais que seriam violados por eventual decisão em sentido contrário. Esse é o ponto essencial. Com efeito, a manutenção do mandato proporcional por parte do parlamentar que troca de partido injustificadamente pode produzir uma violação extremamente grave à regra da representação política, ao tornar potencialmente arbitrárias as regras de contagem dos votos. Evitar esse

89 STF, MS 26.602/DF, MS 26.603/DF e MS 26.604/DF, Inf.STF 482, julgamento em 04.10.2007, Rels. Mins. Eros Grau, Celso de Mello e Carmen Lúcia. O STF chancelou o entendimento manifestado pelo TSE de que "os partidos políticos e as coligações partidárias têm o direito de preservar a vaga obtida pelo sistema eleitoral proporcional, se, não ocorrendo razão legítima que o justifique, registrar-se ou o cancelamento de filiação partidária ou a transferência para legenda diversa, do candidato eleito por outro partido" 
resultado inconstitucional justifica a construção jurídica realizada pelo STF. Explica-se o argumento.

Como se sabe, o sistema eleitoral que regula as eleições proporcionais brasileiras coloca a ênfase na votação obtida pelos partidos, que conquistam cadeiras em função do número de vezes que preenchem o quociente eleitoral ${ }^{90}$. As cadeiras obtidas por cada partido são distribuídas segundo a votação pessoal dos candidatos, e isso muitas vezes permite que indivíduos com votação irrisória sejam eleitos, superando candidatos com desempenho eleitoral muito mais expressivo ${ }^{91}$. A lógica do sistema é privilegiar o conteúdo ideológico dos programas partidários, em lugar do aspecto puramente pessoal. A troca arbitrária de partido acaba com essa racionalidade e pode dar origem ao exercício de mandatos sem a correspondente base eleitoral. Em outras palavras, sem que o povo tenha feito a escolha: quer da pessoa, quer da plataforma política sob a qual se dará sua atividade parlamentar.

Trata-se de verdadeira fraude à representação e, portanto, violação direta ao princípio democrático. Nenhum dispositivo constitucional chancela esse resultado. Tanto assim que a crítica mais relevante que se fez à decisão foi eventual desrespeito à reserva legal e, por conseguinte, à separação dos Poderes. No entanto - sem desmerecer a importância do argumento em tese - a identificação de uma eleição sem votos parece constituir uma hipótese necessária de perda do mandato, mesmo que não esteja elencada no rol supostamente taxativo do art. 55 da Carta. O que o STF fez foi extrair a conseqüência do sistema constitucional ${ }^{92}$, assim como poderia ter declarado a inconstitucionalidade de lei que eventualmente dissesse o contrário.

Para não se tornar autoritária, porém, a decisão do Tribunal deve se abrir às múltiplas possibilidades de diálogo institucional por ela favorecidas. O legislador pode, e.g., modificar

90 Uma descrição objetiva do sistema pode ser encontrada em Gilmar Ferreira Mendes, Inocêncio Mártires Coelho e Paulo Gustavo Gonet Branco, Curso de direito constitucional, 2007, pp. 706 e 707.

91 Em tese, o sistema permite que um indivíduo seja eleito sem ter recebido nenhum voto válido, bastando que seu partido haja conquistado a vaga e não haja outros candidatos mais votados na mesma agremiação. $\mathrm{O}$ exemplo, aparentemente acadêmico, ocorreu de fato em 1945, como relatam os autores citados na nota acima (p. 706). Longe de constituir exceção caricata, o STF levou em consideração o dado de que a imensa maioria dos candidatos não obtém votos pessoais suficientes para preencher o quociente eleitoral. E os casos de votação inexpressiva são igualmente corriqueiros. Em 2002, com a votação recorde de cerca de 1,5 milhões de votos, Enéias Carneiro foi eleito Deputado Federal por São Paulo, o que rendeu ao seu partido o direito a 6 cadeiras na Casa. Dos 5 "caronas", 4 deles tiveram menos de 1000 votos, sendo o último eleito com apenas 285 votos. Um último dado, apenas para sublinhar uma vez mais o caráter determinante da filiação partidária no sistema proporcional brasileiro: nas mesmas eleições, o ex-prefeito de São Paulo Celso Pitta recebeu 83.415 votos, mas não foi eleito em razão do fraco desempenho dos demais candidatos de seu partido.

92 Nesse sentido, o raciocínio jurídico se aproxima daquele empreendido na ADC 12, na qual se considerou que a vedação ao nepotismo no Poder Judiciário poderia ser extraída diretamente do núcleo de princípios constitucionais como a impessoalidade e amoralidade administrativas. Como se sabe, posteriormente o STF estendeu aos demais Poderes a mesma regra, que foi cristalizada na Súmula Vinculante $\mathrm{n}^{\mathrm{o}} 13$. 
os contornos do sistema eleitoral, criando regras que condicionem a eleição a determinado percentual mínimo de votação individual. Embora essa não pareça uma boa opção política, aumentaria a representatividade pessoal dos eleitos, modificando a realidade sobre a qual decidiu o tribunal. Isso talvez pudesse justificar a superação da nova hipótese de perda do mandato. Outra opção seria a troca do sistema proporcional pelo distrital ou distrital misto, o que também poderia justificar - no todo ou em parte - a modificação da conseqüência imposta pelo STF.

Por fim, mesmo sem nenhuma alteração no sistema eleitoral, é razoável considerar que a decisão do Tribunal não deve ser tomada, em toda a sua extensão, como uma exigência constitucional acabada. Mantida a realidade fática, o legislador não pode determinar a manutenção do mandato tout court, mas poderia legislar sobre a caracterização das trocas justificadas de partido, conformando as hipóteses indicadas pelo STF - e.g. identificando condutas partidárias que denotem perseguição política ou desvio ideológico da agremiação -, ou mesmo adicionando novas previsões.

É claro que qualquer inovação legislativa estaria sujeita ao controle de constitucionalidade, mas teria de ser analisada em seu mérito, observando-se a presunção de validade. E talvez até uma presunção reforçada, em deferência ao diálogo institucional que teria se instaurado a partir da decisão judicial altamente interventiva. O fundamento dessa deferência adicional não seria uma estratégia de cessões recíprocas - típica da lógica política -, mas sim a regra geral da autocontenção judicial, em respeito à conformação legislativa dos detalhes de uma orientação constitucional básica imposta pela Corte. Todavia, ainda que rejeite a ideia de deferência qualificada, o que não se deve ter por legítimo é um eventual argumento de desacato a suposta interpretação constitucional autêntica - e exauriente - que teria sido realizada pelo $\mathrm{STF}^{93}$. Com essas observações, passa-se ao estudo da outra decisão.

O destaque negativo do ativismo vai para a decisão proferida na ADPF 46, em que se declarou recepcionado o monopólio postal, sob a forma de serviço público ${ }^{94}$. A crítica não vai para o mérito da decisão - embora haja fortes razões para considerá-la equivocada ${ }^{95}$ - mas sim para os argumentos utilizados. Com efeito, boa parte dos votos vencedores utiliza como argumento explícito considerações de ordem econômica, assumindo a premissa de que a

93 Remete-se à crítica à decisão do STF na ADIn 2.797/97, na qual a Corte procurou desqualificar a possibilidade de o legislador introduzir na ordem jurídica uma interpretação constitucional diversa da adotada pelo Tribunal. V. nota 85.

$94 \quad$ STF, ADPF 46/DF, Rel. p/ o acórdão Min. Eros Grau, decisão em 05.08.2009.

95 Defendendo a não recepção do monopólio postal e a abertura da atividade à iniciativa privada em concorrência com a empresa pública federal, v. Luís Roberto Barroso, "Regime constitucional do serviço postal. Legitimidade da atuação da iniciativa privada". In: Temas de direito constitucional, t. II, 2009, pp. 145-88. 
viabilidade financeira dos Correios dependeria de uma espécie de subsídio cruzado: atividades lucrativas como a entrega de correspondência comercial nos grandes centros urbanos ajudariam a custear a entrega deficitária de correspondência pessoal nos rincões do país. Sem desqualificar de plano a legitimidade de um enfoque consequencialista, houve pelo menos duas fragilidades na sua aplicação ao caso, comprometendo a consistência de sua base jurídica:

(I) o Tribunal baseia seu juízo em premissas econômicas, mas sequer fez esforço para testá-las ou exigiu demonstração da parte que empregou o argumento: os ministros não fizeram qualquer menção a elementos capazes de demonstrar que as atividades supostamente deficitárias de fato o são, tampouco à inviabilidade de eventual subsídio cruzado sob um mercado concorrencial. Tampouco se enfrentou o argumento de que a concorrência já está instalada de fato há cerca de duas décadas, sem impedir que os Correios registrem crescimento anual em suas taxas de lucro;

(II) o Tribunal não reconduz os argumentos consequencialistas a premissas normativas. Qual o fundamento constitucional que impede a eventual redução das perspectivas de lucro de uma empresa pública? E de que forma esse suposto fundamento se relaciona com o argumento central da tese oposta, de violação à livre iniciativa?

Sem a recondução a argumentos normativos, o consequencialismo se aproxima excessivamente da lógica das decisões políticas. Especialmente quando se baseia em premissas de fato não testadas, nem mesmo com a providência mínima e intuitiva que seria a análise dos resultados operacionais da empresa em cada ramo da atividade. O ponto aqui não é de respeito à capacidade institucional de outra instância decisória, que sequer existia no caso. O que se verifica - pelo menos em relação a esse argumento - é uma decisão que se aproxima muito da lógica parlamentar, fundando-se em um juízo velado de conveniência política. Com dois agravantes: (i) os elementos de suporte dessa conveniência não foram testados; e (ii) o juízo político é apresentado sob a forma de exigência jurídica - e com status constitucional - o que acaba dificultando e até desorientando a crítica pública, que se vê obrigada a questionar a própria premissa de que a matéria estaria excluída da política majoritária. Cria-se, portanto, uma barreira indevida em favor de uma escolha política.

Repita-se, uma vez mais, que a crítica não se direciona propriamente ao mérito da decisão, que poderia ter sido o mesmo a partir, unicamente, de uma interpretação semântica do art. 22, X, da Constituição, segundo o qual compete à União "manter o serviço postal". Mesmo por esse fundamento isolado, porém, não seria a melhor decisão, já que o tribunal estaria impondo uma opção interpretativa - afirmar a existência de um serviço público não- 
expresso - em lugar de permitir às instâncias políticas que confiram ao dispositivo um sentido mais adaptado à avaliação dominante em cada momento histórico. Por essa vertente, teria sido possível até declarar a lei recepcionada e a existência de um serviço público por decisão legal, no espaço de apreciação criado pelo dispositivo constitucional lacônico. Mas não afirmar que a natureza de serviço público exclusivo decorreria necessariamente da própria Constituição. O resultado foi um fechamento indevido - ainda que provisório - da textura aberta da Constituição nessa matéria. E isso para inchar a categoria dos serviços públicos exclusivos apesar de seu franco declínio na paisagem institucional brasileira por obra do próprio legislador ${ }^{96}$.

\section{Conclusões}

Sem a intenção de resumir os argumentos expostos e as aplicações que lhes foram dadas, o percurso desenvolvido no presente estudo passa pelas seguintes etapas principais: 1) O fundamento da democracia é o reconhecimento de igual dignidade aos membros de determinada comunidade. Disso decorre a regra da maioria para a tomada de decisões vinculantes para todos. Sob perspectiva filosófica, as decisões majoritárias que venham a negar tratamento igualmente digno a todos os indivíduos subvertem a premissa democrática e interrompem a cadeia de legitimidade do processo, convertendo-se em dominação. Sob perspectiva pragmática, a degradação das minorias impede ou dificulta sua ascensão no espaço público, produzindo uma reserva de poder em favor das maiorias. É nesses dois

\footnotetext{
96 O STF parece ter incidido na crítica de Cláudio Souza Neto e José Vicente Mendonça. Embora seja possível imaginar que os autores tinham em mente um possível fechamento do debate no sentido inverso - por uma decisão afirmando que o texto constitucional teria imposto a caracterização do serviço postal como atividade econômica livre à iniciativa privada - as considerações por eles deduzidas parecem plenamente aplicáveis. V. "Fundamentalização e fundamentalismo na interpretação do princípio constitucional da livre iniciativa". In: Cláudio Pereira de Souza Neto e Daniel Sarmento (orgs), A constitucionalização do direito Fundamentos teóricos e aplicações específicas, 2007, p. 733: "Não pretendemos propor uma solução para o problema suscitado na ADPF - que é multifacetado, envolvendo desde questões de Direito Constitucional intertemporal até detalhes sobre as diversas modalidades de serviço postal. O que se pretende sustentar é, tão-só, a inadequação de se argumentar, no exercício da jurisdição constitucional, com apoio em doutrinas particulares acerca de qual é o melhor modelo de Estado. Em uma república democrática e pluralista, os espaços próprios desse tipo de argumentação são a esfera pública informal e os fóruns oficiais de decisão majoritária. A vocação dessas razões é disputar, com outras, a adesão das maiorias. As razões de que podem dispor as cortes constitucionais são diferentes: razões politicamente imparciais, engajadas na preservação da estrutura básica do Estado Democrático de Direito. Ao dar a um órgão não-eletivo o poder de proferir a última palavra acerca de sua interpretação, a Constituição o faz sob a reserva republicana de imparcialidade política".
} 
aspectos que se pode falar em uma interdependência entre a autonomia moral, entre direitos fundamentais e soberania popular.

2) Essa idéia básica de autogoverno foi implementada com as revoluções liberais, mas de forma limitada. O parlamento foi idealizado como veículo da razão (burguesa), não se admitindo que os limites inerentes à democracia pudessem ser efetivamente impostos às maiorias. A ascensão do Estado social produziu um começo de substantivação da democracia, mas não ainda sob a forma de limites à deliberação majoritária. O processo político concedeu, o que pode ser explicado pela necessidade de conter as tensões sociais e como consequiência da ampliação do sufrágio.

3) O segundo pós-guerra produziu a universalização de uma versão forte de democracia substancial, dotada de uma pretensão efetiva de limitação das maiorias em favor da exigência de igual dignidade. Em um mundo desencantado, tais limites tinham de ser justificados no espaço público, gerando a reabilitação do conceito de razão prática. A própria ideia de autogoverno - de todos, e não apenas das maiorias - traz em si a exigência de justificação das decisões, que devem estar sujeitas permanentemente à crítica pública e à possibilidade de revisão. Assim, a democracia substantiva se assenta também em uma legitimação deliberativa ou discursiva, como complemento e até contraponto à legitimação majoritária. Essa é uma exigência aplicável a todas as manifestações de poder.

4) A legitimação discursiva produz um movimento de dupla aproximação entre a política e o direito. Em certo sentido, a política se constitucionaliza, já que se vê obrigada a traduzir suas pretensões nessa linguagem constitucional mínima. Veja-se que não se trata de converter a política em instância de aplicação do direito constitucional positivo, já que as próprias normas constitucionais não são - apenas pelo seu status formal - imunes à possibilidade de crítica e revisão. A exigência mínima é que as pretensões políticas respeitem o direito que cada indivíduo ostenta de somente se submeter a decisões que sejam fundamentadas em argumentos compatíveis com sua igual dignidade.

5) O que se chamou de constitucionalização da política não equivale a uma imposição externa autoritária. Ao contrário, a universalização do discurso democrático faz com que seja até natural, do ponto de vista estratégico, que qualquer político com pretensões mais sérias se atenha à linguagem mínima dos direitos, ainda quando pretenda excluir determinadas situações da sua esfera de aplicação. As diferentes visões de mundo e mesmo as insinceridades no discurso devem ser equacionadas ou denunciadas no próprio ambiente deliberativo. Também não se trata de uma idealização ingênua, uma vez que a validade do modelo não se assenta em sua suposta capacidade de promover a deliberação desinteressada, 
mas sim na necessidade de crítica pública aberta e permanente sob a exigência argumentativa de respeito à igual dignidade. O ponto é, portanto, mais pragmático: nenhuma verdade revelada vai cair como um raio para purificar os processos decisórios, em qualquer dos Poderes. É necessário privilegiar um desenho institucional que, da melhor maneira possível, promova a democracia em sua versão substancial.

6) A exigência de respeito à igual dignidade é um parâmetro argumentativo e não matemático, a ser equacionado no espaço público. Em última instância, são mesmo as maiorias - ou, antes, as forças dominantes - que definem os limites últimos à sua atuação. Mesmo a Constituição pode ser modificada ou substituída. Da mesma forma, eventuais instâncias contramajoritárias - como a jurisdição constitucional - não durariam para sempre caso se opusessem sistemática e radicalmente ao projeto político básico das maiorias. O que a democracia deliberativa faz é destacar a necessidade de que o ponto de equilíbrio seja definido no espaço público, com possibilidade de crítica ampla e permanente. Isso força as maiorias a justificar suas posições, expondo fragilidades e podendo diluir radicalismos.

7) Em essência, portanto, o que a democracia deliberativa exige é a possibilidade permanente de crítica e revisão das decisões no espaço público, tendo a igual dignidade como parâmetro argumentativo. Em tese, o controle das decisões majoritárias em face desse parâmetro poderia ser não-formal, pressupondo-se internalizado ao processo político. Sem prejuízo disso, há inegáveis vantagens na existência de instâncias formais de controle, que criam um momento deliberadamente reflexivo. Isso não significa, ainda, que o controle tenha de ser jurisdicional. Seria possível cogitar, por exemplo, de uma comissão parlamentar encarregada de analisar a validade das decisões majoritárias, submetida à exigência de fundamentar suas decisões.

8) No entanto, tampouco há impedimentos à criação de mecanismos de controle baseados essencialmente na legitimação discursiva, integrados por agentes não-eleitos. Nesse sentido, a jurisdição constitucional pode até não ser indispensável, mas tampouco precisa ser vista como uma força externa ao processo democrático. Essa é uma questão de desenho institucional, que pode combinar a legitimação majoritária e a legitimação discursiva de diferentes formas.

9) A jurisdição constitucional apresenta algumas vantagens sob o ponto de vista da legitimação discursiva: i) a jurisdição constitucional está sujeita a uma exigência de neutralidade - imparcialidade - o que nunca poderia ser efetivamente cobrado de agentes propriamente políticos. Em outras palavras, acomodações estratégicas de interesse não fazem parte da sua lógica normal de atuação, podendo ser denunciadas; ii) está sujeita a um dever reforçado de fundamentação, expondo-se de forma privilegiada à crítica pública. Inclusive pela necessidade de reconduzir suas decisões a fundamentos normativos - que podem ser 
modificados, em alguma medida, pelas instâncias eleitas -, e não meramente de conveniência política; iii) é uma instância relativamente desarmada das armas políticas. Diante de tais elementos, situar a palavra (provisoriamente) final no Judiciário pode forçar a produção de um equilíbrio deliberativo, e não pela mera imposição das forças sociais dominantes.

10) É lógico que a realização dessas condições é controlada no interior do próprio processo deliberativo, em sentido mais amplo. A própria graduação do papel da jurisdição constitucional dependerá de fatores diversos, podendo oscilar entre períodos de maior ativismo ou autocontenção. Não há como fugir disso. O equilíbrio deliberativo acima referido é dinâmico, e não estático. De qualquer forma, mesmo em seus momentos de maior prestígio, a jurisdição constitucional nunca pode ter a pretensão de ser a dona do processo deliberativo, fechando-se ao diálogo com as demais instâncias de poder. Ao contrário, as condições mencionadas no item 8 - que conferem legitimidade a sua atuação - já pressupõem respeito às avaliações políticas razoáveis dos agentes eleitos. É possível esgarçar a corda até certo ponto, mas não indefinidamente.

\section{Bibliografia}

ALEXY, Robert. La institucionalización de la justicia. Granada: Comares, 2005.

. "Ponderação, jurisdição constitucional e representação popular". In: SARMENTO, Daniel; e SOUZA NETO, Cláudio Pereira de. A constitucionalização do direito - Fundamentos teóricos e aplicações específicas, 2007.

AMARAL, Gustavo. Direito, escassez e escolha. Rio de Janeiro: Renovar, 2001.

ARAGÃO, Alexandre Santos de. Agências reguladoras e a evolução do direito administrativo econômico. Rio de Janeiro: Forense, 2006.

Direito dos serviços públicos. Rio de Janeiro: Forense, 2007.

ÁVILA, Humberto. Teoria dos princípios. São Paulo: Malheiros, 2003.

BARAK, Aharon. The judge in a democracy. Princeton: Princeton University Press, 2006.

BARCELLOS, Ana Paula de. A eficácia jurídica dos princípios constitucionais - O princípio da dignidade da pessoa humana. Rio de Janeiro: Renovar, 2002.

Renovar, 2005

Ponderação, racionalidade e atividade jurisdicional. Rio de Janeiro:

BARROSO, Luís Roberto. O controle de constitucionalidade no Direito brasileiro. São Paulo: Saraiva, 2008. 
. Curso de direito constitucional contemporâneo - Os conceitos fundamentais e a construção do novo modelo. São Paulo: Saraiva, 2009.

. Interpretação e aplicação da Constituição. São Paulo: Saraiva, 2009.

. Neoconstitucionalismo e a constitucionalização do Direito (O triunfo tardio do direito constitucional no Brasil), Revista de Direito Administrativo, n 240, 2005.

Mudança da jurisprudência do Supremo Tribunal Federal em matéria tributária. Segurança jurídica e modulação dos efeitos temporais das decisões judiciais, Revista de Direito do Estado ${ }^{\circ}$ 2, 2006.

"Regime constitucional do serviço postal. Legitimidade da atuação da iniciativa privada". In: Temas de direito constitucional, t. II. Rio de Janeiro-São Paulo: Renovar, 2009.

. Judicialização, ativismo judicial e legitimidade democrática, Revista de Direito do Estado no 13, 2009.

BAPTISTA, Patrícia. Transformações do direito administrativo. Rio de Janeiro: Renovar, 2003.

BINENBOJM, Gustavo. Uma teoria do direito administrativo - Direitos fundamentais, democracia e constitucionalização. Rio de Janeiro-São Paulo: Renovar, 2006.

BINENBOJM, Gustavo; e CYRINO, André Rodrigues. "Parâmetros para a revisão judicial de diagnósticos e prognósticos regulatórios em matéria econômica". In: SARMENTO, Daniel; SOUZA NETO, Cláudio; e BINENBOJM, Gustavo. Vinte anos da Constituição Federal de 1988 (coords.). Rio de Janeiro: Lumen Juris, 2009.

BONAVIDES, Paulo. Do Estado Liberal ao Estado Social. 6 ${ }^{\mathrm{a}}$ ed., São Paulo: Malheiros, 1996.

BUCHANAN, James. Politics as public choice. Indianapolis: Liberty Fund, 2000.

CATTONI, Marcelo, Direito, política e filosofia, Rio de Janeiro: Lumen Juris, 2007.

CLÈVE, Clèmerson Merlin. Atividade legislativa do Poder Executivo. São Paulo: Revista dos Tribunais, 2000.

CITTADINO, Gisele. Judicialização da política, constitucionalismo democrático e separação dos Poderes. In: Luiz Werneck Vianna, A democracia e os três Poderes no Brasil. Rio de Janeiro: IUPERJ/FAPERJ, 2002.

CLÉRICO, Laura. Die Struktur der Verhältnismäßigkeit. Baden-Baden: Nomos, 2001.

DAHL, Robert. On democracy. New Haven: Yale University Press, 2000.

DALLARI, Dalmo de Abreu. Teoria geral do Estado. São Paulo: Malheiros, 1998.

DWORKIN, Ronald. Freedom's Law - The moral reading of the American Constitution, Cambridge: Harvard University Press, 1996. 
ENTERRÍA, Eduardo García de. La Constitución como pacto social y como norma jurídica. Madrid: Inap, 2003.

EPSTEIN, David e O'HALLORAN, Sharyn. Delegating powers - A transaction cost politics approach to policy making under separate Powers. Cambridge: Cambridge University Press, 1999.

FARIA, José Eduardo. Política, sistema jurídico e decisão judicial. São Paulo: Martins Fontes, 2002.

FEELEY, Malcolm e RUBIN, Edward. Judicial policy making and the modern State - How courts reformed America's prisons. Cambridge: Cambridge University Press, 2000.

FERNANDEZ SEGADO, Francisco. La justicia constitucional: una visión de derecho comparado, tomo I. Madrid: Editorial Dykinson, 2009.

FERRAJOLI, Luigi. Pasado y futuro del Estado de derecho. In: Miguel Carbonell (org.), Neoconstitucionalismo(s). Madrid: Editorial Trotta, 2003.

FERREIRA FILHO, Manoel Gonçalves. Processo legislativo. $6^{\mathrm{a}}$ ed., São Paulo: Saraiva, 2007.

FLEINER-GERSTER, Thomas. Teoria geral do Estado. São Paulo: Martins Fontes, 2006.

FORST, Rainer. Das Recht auf Rechtfertigung - Elemente einer konstruktivistischen Theorie der Gerechtigkeit. Frankfurt a.M: Suhrkamp, 2007.

GOUVÊA, Marcos Maselli. O controle judicial das omissões administrativas - Novas perspectivas de implementação dos direitos prestacionais. Rio de Janeiro: Forense, 2003.

GRIFFIN, Stephen. American constitutionalism. Princeton: Princeton University Press, 1998.

GRIMM, Dieter. Die Zukunf der Verfassung. Frankfurt a.M: Suhrkamp, 1991.

1987. Recht und Staat der bürgerlichen Gesellschaft. Frankfurt a.M: Suhrkamp, Constituição e política. Belo Horizonte: Del Rey, 2006.

2006. . Jurisdição constitucional e democracia, Revista de Direito do Estado $\mathrm{n}^{\circ} 4$,

HÄBERLE, Peter. Hermenêutica Constitucional - A sociedade aberta dos intérpretes da Constituição - Contribuição para a interpretação pluralista e procedimental da Constituição. Porto Alegre: Sergio Fabris, 1997.

HABERMAS, Jürgen. Faktizität und Geltung - Beiträge zur Diskurstheorie des Rechts und des demokratischen Rechtsstaats. $4^{\text {a }}$ ed., Frankfurt a.M: Suhrkamp, 1998.

Brasileiro, 2007. Entre naturalismo e religião. Estudos filosóficos. Rio de Janeiro: Tempo 
KAUFMANN, Arthur; HASSEMER, Winfried e NEUMANN, Ulfried (orgs.). Einführung in die Rechtsphilosophie und Rechtstheorie der Gegenwart. $7^{\mathrm{a}}$ ed., Heidelberg: C.F. Muller, 2004.

HESSE, Konrad. Grundzüge des Verfassungsrechts des Bundesrepubliks Deutschlands. 19a ed., Heidelberg: C.F. Müller, 1993.

HIRSCHL, Ran. Towards juristocracy. Cambridge: Harvard University Press, 2007.

HUBER, John D. e SHIPAN, Charles R. Deliberate discretion - The institutional foundations of bureaucratic autonomy. Cambridge: Cambridge University Press, 2002.

KELSEN, Hans. Teoria geral do Direito e do Estado. São Paulo: Martins Fontes, 2005. . Jurisdição constitucional. São Paulo: Martins Fontes, 2003.

KIEWIET, D. Roderick e MCCUBBINS, Mathew. The logic of delegation - Congressional parties and the appropriations process. Chicago: The University of Chicago Press, 1991.

KRAMER, Larry. The people themselves: popular constitutionalism and judicial review. Oxford: Oxford University Press, 2004.

KYMLICKA, Will. Contemporary political philosophy - An introduction. Oxford: Oxford University Press, 2002.

LEAL, Rogério Gesta. Esfera pública e participação social: possíveis dimensões jurídicopolíticas dos direitos civis de participação social no âmbito da gestão dos interesses públicos no Brasil, Revista Brasileira de Direito Público, nº19, 2007.

LOPES, José Reinaldo de Lima. Direito subjetivo e direitos sociais: o dilema do Judiciário no Estado Social de Direito. In: FARIA, José Eduardo (org). Direitos humanos, direitos sociais e justiça. São Paulo: Malheiros, 2005.

MAIA, Antonio Cavalcanti. "Nos vinte anos da Carta Cidadã: do pós-positivismo ao neoconstitucionalismo". In: SARMENTO, Daniel; SOUZA NETO, Cláudio; e BINENBOJM, Gustavo. Vinte anos da Constituição Federal de 1988 (coords.). Rio de Janeiro: Lumen Juris, 2009.

MELLO, Cláudio Ari. Democracia constitucional e direitos fundamentais. Porto Alegre: Livraria do Advogado, 2004.

MICHELMAN, Frank. Brennan and democracy. Princeton: Princeton University Press, 2005. Law's republic, 97 Yale Law Journal, 1493, July 1988.

MENDES, Gilmar Ferreira, COELHO, Inocêncio Mártires e BRANCO, Paulo Gustavo Gonet. Curso de direito constitucional. São Paulo: Saraiva, 2007.

MONTEIRO, Jorge Vianna. Lições de economia constitucional. Rio de Janeiro: Editora FGV, 2004. 
MUELLER, Dennis C.. "Constitutional public choice". In: Dennis C. Mueller (Ed.), Perspectives on public choice. Cambridge: Cambridge University Press, 2005.

NINO, Carlos Santiago. La Constitución de la democracia deliberativa. Buenos Aires: Gedisa, 1997. Ética y derechos humanos. $2^{\mathrm{a}}$ ed., Buenos Aires: Astrea, 1989.

PAULO JUNIOR, José Marinho. O poder jurisdicional de administrar - Criação judicial de órgão administrativo. Rio de Janeiro: Lumen Juris, 2007.

RAWLS, John. Liberalismo Político. Mexico: Fondo de Cultura Económica, 1996.

University Press, 2003.

Lectures on the history of moral philosophy. Cambridge: Harvard

ROTHEMBURG, Walther Claudius. "Omissão inconstitucional e troca de sujeito". In: TAVARES, André Ramos. Justiça constitucional - pressupostos teóricos e análises concretas. Belo Horizonte: Fórum, 2007.

SANCHÍS, Luis Prieto. Ley, princípios, Derecho. Madrid: Dykinson, 1998.

SANTOS, Boaventura de Souza. A gramática do tempo - Para uma nova cultura política, v. 4. São Paulo: Cortez, 2006.

SARMENTO, Daniel. Direitos fundamentais e relações privadas. Rio de Janeiro: Lumen Juris, 2004.

"O neoconstitucionalismo no Brasil: riscos e possibilidades". In: SARMENTO, Daniel (coord.), Filosofia e teoria constitucional contemporânea. Rio de Janeiro: Lumen Juris, 2009. Janeiro: Lumen Juris, 2009.

SHAPIRO, Ian. Os fundamentos morais da política. São Paulo: Martins Fontes, 2006.

SILVA, Anabelle Macedo. Concretizando a Constituição. Rio de Janeiro: Lumen Juris, 2005.

SOUZA NETO, Cláudio Pereira de. Teoria constitucional e democracia deliberativa - Um estudo sobre o papel do Direito na garantia das condições para a cooperação democrática. Rio de Janeiro-São Paulo: Renovar, 2006.

SOUZA NETO, Cláudio Pereira de; e MENDONÇA, José Vicente. "Fundamentalização e fundamentalismo na interpretação do princípio constitucional da livre iniciativa". In: SARMENTO, Daniel; e SOUZA NETO, Cláudio Pereira de. A constitucionalização do direito - Fundamentos teóricos e aplicações específicas, 2007.

STRUCHINER, Noel. Direito e linguagem. Rio de Janeiro-São Paulo: Renovar, 2002. 
SUNSTEIN, Cass. Designing democracies. Oxford: Oxford University Press, 2001.

SWEET, Alec Stone. Governing with judges - Constitutional politics in Europe. Oxford: Oxford University Press, 2000.

TORRES, Ricardo Lobo. Tratado de direito constitucional financeiro e tributário, Vol. II Valores e princípios constitucionais tributários. Rio de Janeiro: Renovar, 2005.

TUSHNET, Mark. Taking the Constitution away from the courts. Princeton: Princeton University Press, 2000.

VERMEULE, Adrian. Judging under uncertainty - An institutional theory of legal interpretation. Cambridge: Harvard University Press, 2006.

VERMEULE, Adrian; e GERSEN, Jacob. Chevron as a voting rule, 116 Yale Law Journal, 676, 2006.

VIEIRA, Oscar Vilhena. Supremo Tribunal Federal - Jurisprudência política. São Paulo: Malheiros, 2002.

- Supremocracia. In: SARMENTO, Daniel (coord.), Filosofia e teoria constitucional contemporânea. Rio de Janeiro: Lumen Juris, 2009.

WALZER, Michael. Politics and passion - Towards a more egalitarian liberalism. New Haven: Yale University Press, 2006.

ZAGREBELSKY, Gustavo. El derecho dúctil. Madrid: Editorial Trotta, 2008. 